\title{
Phylogenetic interrelationships of the barbets (Aves: Capitonidae) and toucans (Aves: Ramphastidae) based on morphology with comparisons to DNA-DNA hybridization
}

\author{
R. O. PRUM
}

Museum of Zoology and Department of Biology, University of Michigan, Ann Arbor, Michigan 48109, U.S.A.

A phylogenetic analysis of the interrelationships of the barbets (Capitonidac) and the toucans (Aves: Ramphastidac, Superfamily Ramphastoidea) is presented. Thirty-two morphological characters from the literature and independent osteological observations were analysed. Character polarity was determined by outgroup comparison to the Picidae, Indicatoridae, Galbulidac, Bucconidae and Coraciiformes. Four alternative phylogenetic hypotheses were compared: (1) the overall most parsimonious morphological phylogeny, (2) the most parsimonious morphological phylogeny in which the capitonids and ramphastids were hypothesized as monophyletic sister groups, and (3) and (4) the most parsimonious hypotheses for the evolution of the morphological characters within two proposed DNA-DNA hybridization phylogenies of the ramphastoids. The analysis focused on the higher level relationships of ramphastids and capitonids and interrelationships among capitonid genera. Two cladistic analyses were performed using 26 phylogenetically informative characters, and the PAUP and CONTREE computer alogorithms. The most parsimonious morphological phylogeny required fewer character changes and had a lower consistency index than any of the alternative hypotheses but congruence between the most parsimonious phylogeny and the second, revised DNA-DNA hybridization hypothesis was very high. Based on these results the monophyly of the Capitonidae is rejected. The ramphastids and the Neotropical capitonids form a well corroborated clade within the pantropical ramphastoid radiation. Neither the African, Asian nor New World capitonids is monophyletic. 'The genus Trachyphonus is the sister group to all other capitonids and ramphastids. The sister group to the ramphastids is the genus Semnomis. 'The interrelationships of the Old World capitonids excluding Trachyphonus are not completely resolved by these morphological data but one of the alternative phylogenetic resolutions is presented as a preliminary hypothesis. The clades in this resolved phylogeny are diagnosed and the palacontology and biogeography of the ramphastoids are reviewed in light of this new evidence. A phylogenetic classification is proposed in which the Capitonidae is rejected and the capitonids and ramphastids are placed in seven subfamilies of the Ramphastidac.

KEY WORDS:-Barbets - toucans - Capitonidac - Ramphastidac - phylogenctic systematics morphology - DNA-DNA hybridization - palaeontology - biogeography.

\section{CONTENTS}

Introduction . . . . . . . . . . . . . . . . . . 314

Recent classifications of the Piciformes and the Ramphastoidea . . . . . . . . 315

Methods . . . . . . . . . . . . . . . . . . . . 317 


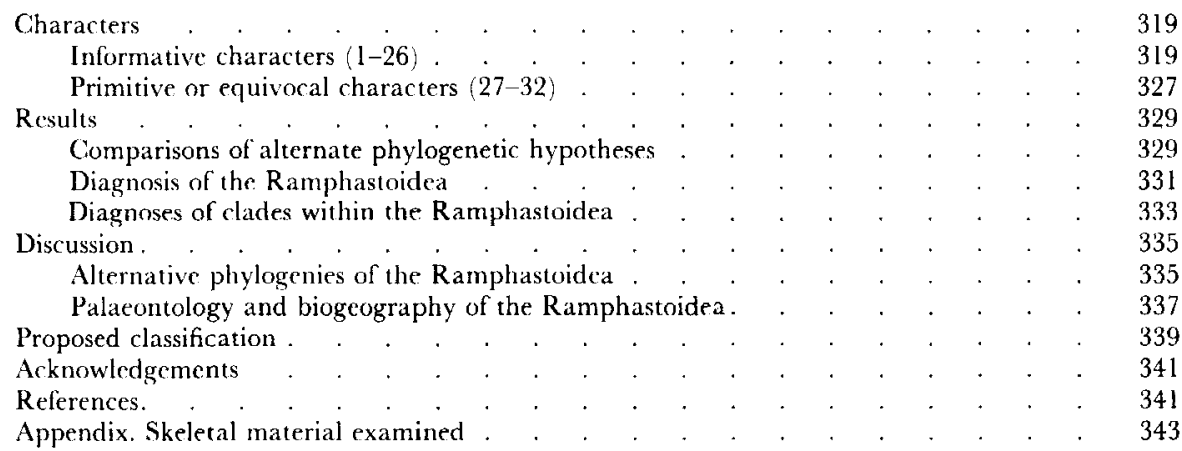

\section{IN'TRODUCIION}

The pantropical barbets (Aves: Capitonidae) have been traditionally considered a well circumscribed and homogeneous group of piciform birds (Sclater, 1891; Beddard, 1898; Ridgway, 1914; Ripley, 1945; Goodwin, 1964). Though the limits of the family Capitonidae have been expanded at various times to include other piciform groups, such as the honeyguides (Indicatoridae) and the toucans (Ramphastidae) (e.g. Garrod, 1878), the barbets have been consistently placed in an exclusive taxonomic category since their first description (Sclater, 1861, 1891; Marshall \& Marshall, 1870; Garrod, 1878; Beddard 1896, 1898; Ridgway, 1914; Stresemann, 1934; Ripley, 1945; Peters, 1948; Verheyen, 1955; Wetmore, 1960; Goodwin, 1964; Wolters, 1976; Simpson \& Cracraft, 1981; Swierczewski \& Raikow, 1981). Despite this taxonomic stability, the strict monophyly of the Capitonidae has not been demonstrated and recent anatomical investigation (Burton, 1984) and DNA-DNA hybridization research (Sibley \& Ahlquist, 1985, 1986) have brought into question the modern view of the capitonids as the sister group of the strictly Neotropical toucans (Ramphastidae) (Simpson \& Cracraft, 1981; Swierczewski \& Raikow, 1981).

In this paper, I present a phylogenetic analysis of traditional characters, morphological evidence from recent literature and independent osteological observations pertaining to the cladistic relationships of the capitonids and ramphastids, which comprise the monophyletic piciform superfamily Ramphastoidea) (Simpson \& Cracraft, 1981; Swierczewski \& Raikow, 1981). Four alternative phylogenetic hypotheses are compared: (1) the overall most parsimonious phylogeny, or the phylogeny which accounts for the observed variation in all the morphological characters with the minimum number of character state changes; (2) the most parsimonious phylogeny in which the capitonids and ramphastids are hypothesized to be monophyletic sister groups (Simpson \& Cracraft, 1981; Swierczewski \& Raikow, 1981); and (3) and (4) the most parsimonious hypotheses for the evolution of the morphological characters within two proposed DNA DNA hybridization phylogenies of the Piciformes (Sibley \& Ahlquist, 1985, 1986). Based on this analysis, I propose a phylogeny and a phylogenetic classification of the Ramphastoidea, and morphological diagnoses of the clades within the superfamily. The analysis focuses on the relationships among lineages of capitonids, and between the ramphastids and 
capitonids. The palaeontology and biogeography of the Ramphastoidea will be discussed in light of this explicit phylogeny. As in recent analyses of the Passeriformes (Raikow, 1982), Tyrannidae (McKitrick, 1985) and Pelicaniformes (Cracraft, 1985), the purpose of this investigation is to reevaluate the monophyly of a traditional taxonomic group in an effort to identify diagnosable clades which will be useful for further comparative biological research.

\section{RECEN'T CLASSIFICATIONS OF THE PICIFORMES AND THE RAMPHASTOIDEA}

The taxonomic history of the Piciformes was reviewed by Sibley \& Ahlquist (1972). Subsequently, Swierczewski \& Raikow (1981) and Simpson \& Cracraft (1981) proposed congruent phylogenies of the Piciformes based on hind-limb musculature and osteology, respectively. Both papers support the monophyly of the Piciformes of Peters (1948), Verheyen (1955), Wetmore (1960) and others. Swierczewski \& Raikow (1981) and Simpson \& Cracraft (1981) proposed the following phylogenetic classification of the order:

Order Piciformes

$$
\begin{gathered}
\text { Suborder Galbulae } \\
\text { Family Bucconidae, Puffbirds } \\
\text { Family Galbulidae, Jacamars } \\
\text { Suborder Pici } \\
\text { Superfamily Ramphastoidea } \\
\text { Family Capitonidae, Barbets } \\
\text { Family Ramphastidae, Toucans } \\
\text { Superfamily Picoidea } \\
\text { Family Indicatoridae, Honeyguides } \\
\text { Family Picidae, Woodpeckers }
\end{gathered}
$$

Swierczewski \& Raikow (1981) and Simpson \& Cracraft (1981) cited several shared derived foot characters which indicate a single, unique common origin of zygodactyly in these six families of birds. Conversely, there has been continued recent support for the traditional placement of the Bucconidae and Galubulidae in or near the Coraciiformes and the recognition of a restricted Piciformes containing only the latter four families (Fürbringer, 1888; Shufeldt, 1891; Beddard, 1898; Lowe, 1946; Sibley \& Ahlquist, 1972, 1985, 1986; Olson, 1983, 1985; Burton, 1984; see also Raikow \& Cracraft, 1983). The monophyly of most of the clades within the phylogenetic classification above was well supported by both hind-limb muscular and osteological characters; the suborder Pici was particularly well corroborated by six hind-limb and three osteological synapomorphies (Simpson \& Cracraft, 1981; Swierczewski \& Raikow, 1981). However, Swierczewski \& Raikow (1981) did not identify any hind-limb muscular synapomorphies of either the Capitonidae or the Ramphastidae. They proposed some intergeneric relationships within these two families after using traditional characters of support the monophyly of each (see characters 12 and 14 below). Simpson \& Cracraft (1981) assumed the monophyly of each of the piciform families and did not present any characters to diagnose them. 
Burton (1984) investigated the anatomy of the feeding apparatus of the Coraciiformes and the Piciformes, and presented an "evolutionary" or eclectic classification of the orders in which he recognized a restricted Piciformes containing only the Capitonidae, Ramphastidae, Picidae and Indicatoridae. Burton (1984) hypothesized that the toucans share a most recent common ancestor with some lineage of New World capitonid (see characters 8, 9, 10 below), but proposed the continued recognition of the Ramphastidae and the paraphyletic Capitonidae as apparently informative evolutionary grades.

Sibley \& Ahlquist $(1985,1986)$ proposed two phylogenies of the Piciformes (sensu stricto) based on DNA-DNA hybridization. In the first, Sibley \& Ahlquist (1985) hypothesized that the Old World capitonids are the monophyletic sister group to the rest of the piciforms and that the New World capitonids and the ramphastids are the sister group to the indicatorids and picids. Using their system of categorical equivalence based on DNA-DNA hybridization distances (Sibley \& Ahlquist, 1983), Sibley \& Ahlquist (1985) proposed the following phylogenetic classification for the Piciformes (sensu stricto):

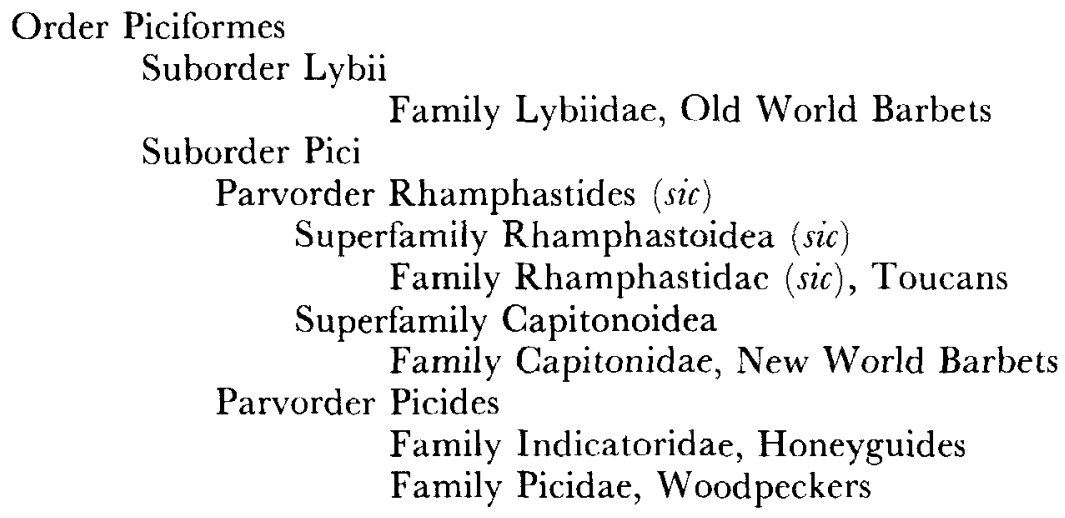

Subsequently, Sibley \& Ahlquist (1986) revised this arrangement based on a larger sample and including adjustments for variation in the rate of genomic evolution which is correlated with age at first maturity (C. G. Sibley, personal communication). They proposed that the capitonids and ramphastids are the monophyletic sister group to the indicatorids and picids and that the Old World capitonids are the sister group to the New World capitonids and ramphastids:

Order Piciformes

Parvorder Picida

Family Picidae, Woodpeckers

Family Indicatoridae, Honeyguides

Parvorder Ramphastida

Superfamily Megalaimoidea

Family Megalaimidae, Old World Barbets

Superfamily Ramphastoidea

Family Ramphastidae

Subfamily Ramphastinae, Toucans

Subfamily Capitoninae, New World Barbets

Almost all systematic treatments of the capitonids have assumed the monophyly of each of the three, discrete geographic assemblages-African, 
Asian and New World (Marshall \& Marshall, 1870; Berlioz, 1936; Ripley, 1945; Goodwin, 1964) but these hypotheses have yet to be supported by shared derived characters. Swierczewski \& Raikow (1981) proposed that Trachyphonus is the sister group to the rest of the capitonids. Following Burton (1984), it has been recognized that ramphastids may be a lineage of New World capitonids (Short, 1985; Short \& Horne, 1985). Ripley (1945), Goodwin (1964), Short \& Horne (1985) and Short (1985) discussed the relationships among Old World capitonids and proposed various classifications which summarize evolutionary, ecological and behavioural aspects of their diversification. Within the ramphastids, Haffer (1974) analysed the speciation and biogeography of the ramphastids in great detail as part of an investigation of the Pleistocene refugia hypothesis, and proposed a revised classification of the ramphastids including superspecific categories and some revisions of biological species limits within certain genera.

\section{METHODS}

Following Swierczewski \& Raikow (1981) and Simpson \& Cracraft (1981), the monophyly of the suborder Pici and the superfamilies Ramaphastoidea and Picoidea was accepted for this analysis. All genera of capitonids were analysed as separate taxa. For the most part, the ramphastids were treated as a single, monophyletic group. For the taxonomy and genetic limits of the capitonids, the treatment of Peters (1948) was followed for Asian and Neotropical forms and the classification of Short \& Horne (1985) was followed for African taxa.

Characters were taken from the literature, from observations of skins housed in the University of Michigan Museum of Zoology, and from observations of skeletal specimens in the collections of the University of Michigan Museum of Zoology, the American Museum of Natural History, the United States National Museum of Natural History and the Louisiana State University Museum of Natural History. The skeletal material examined is summarized in the Appendix.

Character polarity within the ramphastids and capitonids was determined by outgroup comparison (Eldredge \& Cracraft, 1980; Stevens, 1980; Wiley, 1981; Maddison, Donoghue \& Maddison, 1984) to the Picidae, Indicatoridae, Galbulidae, Bucconidae and Coraciiformes. The Gabulidae and Bucconidae were treated as distant outgroups which may or may not comprise the actual sister group to the entire Pici; the character polarity assignments in this analysis should not be affected by whether or not the Piciformes (sensu lato) are monophyletic.

In each of the 32 character descriptions, the hypothetical derived state and its distribution are presented first, followed by the description of the primitive state found in the outgroups and some portion of the ingroup. A discussion of previous hypotheses for the polarity and evolution of the character may be included. Characters 3-4 and 6-7 were hypothesized to have been derived in transition series; taxa derived for characters 4 and 7 were coded as derived for 3 and 6 , respectively. In six instances where character distributions taken from the literature were incomplete, missing taxa were coded as unknown (?). Although the monophyly of the Ramphastoidea was accepted a priori here, several characters which pertain to the monophyly of this group are included below in 
order to provide a revised diagnosis of the superfamily. Six characters (27-32) which have appeared in previous descriptions or diagnoses of Capitonidae, but which appear to be primitive within the Ramphastoidea or equivocal given present knowledge, are discussed below but were not included in the cladistic analyses. The complete matrix of the 26 informative characters and the general geographic distributions of each taxon analysed are presented in Table 1.

Four alternative phylogenetic hypotheses were compared in the cladistic analyses: (1) the phylogenies which accounted for all the observed characters with the minimum number of character state changes (including both advances and reversals); (2) the most parsimonius hypotheses for the evolution of the characters in which the Capitonidae and the Ramphastidae are hypothesized to be monophyletic sister groups (Simpson \& Cracraft, 1981; Swierczewski \& Raikow, 1981); and the most parsimonious hypotheses for the evolution of the morphological characters in (3), the first DNA-DNA hybridization phylogeny of the Piciformes (Sibley \& Ahlquist, 1985) in which the Old World capitonids are the sister group to the Picoidea and the New World ramphastoids, and the New World capitonids and the ramphastids are sister groups; and (4) the revised DNA DNA hybridization phylogeny (Sibley \& Ahlquist, 1986) in which the Old World capitonids are the sister group of the monophyletic New World capitonids and ramphastids.

Two separate cladistic analyses were done using the PAUP (version 2.3) computer algorithm (Swofford, 1983a). In the first analysis, all 16 taxa and 26 informative characters were used. The most parsimonious trees were identified using the PAUP algorithm with the global branch-swapping and mulpars options on the ordered character set. The PAUP algorithm was also used to calculate the total branch length (number of character state changes) and the consistency index $\langle\mathrm{CI}=$ number of binary characters/number of character state changes; Kluge \& Farris, 1969) for each of these trees as estimates of convergence, or homoplasy. The morphological characters analysed here were insufficient to resolve the relationships among the genera of Old World capitonids cxcluding Trachyphonus, so many equally parsimonious resolutions $(>100)$ were identified. However, a strict-consensus tree of all the most parsimonious trees was identified using the CONTREE (version 5) computer algorithm (Swofford, 1983b). In this consensus tree, the interrelationships of Trachyphonus, the ramphastids and all the New World capitonids were resolved. The PAUP was then used to calculate the total branch length and consistency index of minimum length trees based on hypotheses 2-4 using the usertree option. These trees were identified by rearranging the resolved clades from the consensus tree, above, so as to produce the fewest number of morphological character state changes assuming each hypothesis. The results of this analysis are presented as four consensus trees in which only the interrelationships of Trachyphonus, the New World capitonids and the ramphastids are resolved (Fig. 3). Character state changes cannot be shown on these consensus trees, since this would require choosing one of the many equally parsimonious alternative trees and depicting equivocal, unresolved branches as resolved.

In order to investigate explicity the alternative hypotheses for the evolution of the morphological characters within the resolved clades of the four alternative phylogenetic hypotheses, a second analysis was performed in which the Old World capitonids excluding Trachyphonus were treated as a single generalized 
taxon (i.e. were assumed to be monophyletic) and characters 20-26 (which only pertain to relationships among these genera of Old World capitonids) were left out. The same procedure was followed as above. A single most parsimonious phylogeny was identified using the PAUP algorithm with the global branchswapping and mulpars options on the ordered character set. The most parsimonious hypotheses for the evolution of the morphological characters within the other three alternative hypotheses were identified using the PAUP usertree option. The results of this analysis are presented as resolved trees on which the hypothesized character changes are shown (Fig. 4). Character optimizations were done by hand. Essentially, this second procedure assumes the monophyly of the Old World capitonids, excluding Trachyphonus, in order to investigate more explicitly other levels of relationship among the capitonids and ramphastids.

One of the most parsimonious trees identified by PAUP in the first analysis was selected as a highly plausible, heuristic phylogenetic prediction (Fig. 5). This phylogeny is the most parsimonious resolution assuming the monophyly of the African capitonids exclusive of Trachyphonus. Character optimizations on this phylogeny were done by hand. The phylogenetic classification and diagnoses presented below are based on this resolution.

\section{CHARACIERS}

\section{Informative characters (1-26)}

(1) Burton (1984: 355-359) found the post-orbital ligament absent in all ramphastids and capitonids, and present in all other piciforms and nearly all coraciiforms, though weakly in Indicator and Jynx. 'The absence of the postorbital ligament is here hypothesized as a synapomorphy of the ramphastoids.

(2) Swierczewski \& Raikow (1981, character 22) found a tendinous slip from the M. extensor digitorum longus to digit IV present in all capitonids and ramphastids examined. This tendinous slip was absent in all other piciforms. Following Swierczewski \& Raikow (1981), the former state is hypothesized to be derived.

(3 4) Many authors have reported that the clavicles in some ramphastids and capitonids are reduced in size and do not fuse to form a furcula (Parker, 1867; Beddard, 1898; Newton, 1899; Ridgway, 1914; Stresemann, 1934; Van Tyne \& Berger, 1959; George \& Berger, 1966). Verheyen (1955) observed that the furcula of many Old World capitonids is composed of three parts, including the two reduced clavicles and a third, medial bone that forms the ventral or sternal apex of the furcula; whereas in the ramphastids and the Old World capitonid genera Megalaima and Pogoniulus, this third, medio-ventral bone is absent and the reduced clavicles do not meet ventrally to form a furcula.

In all ramphastids, New World capitonids and Old World capitonids in the genera Megalaima, Psilopogon, Buccanodon and Pogoniulus examined here, the clavicles are thin and short, and extend ventrally from their widened bases (or epicleidia) but do not fuse medially to form a furcula (Fig. 1D). In all other capitonids examined, the clavicles are of similar size and shape but articulate to a third chevron-shaped bone which forms the ventral apex of the furcula (Fig. 1B, C). This third independent bone is dorso-ventrally compressed, often 


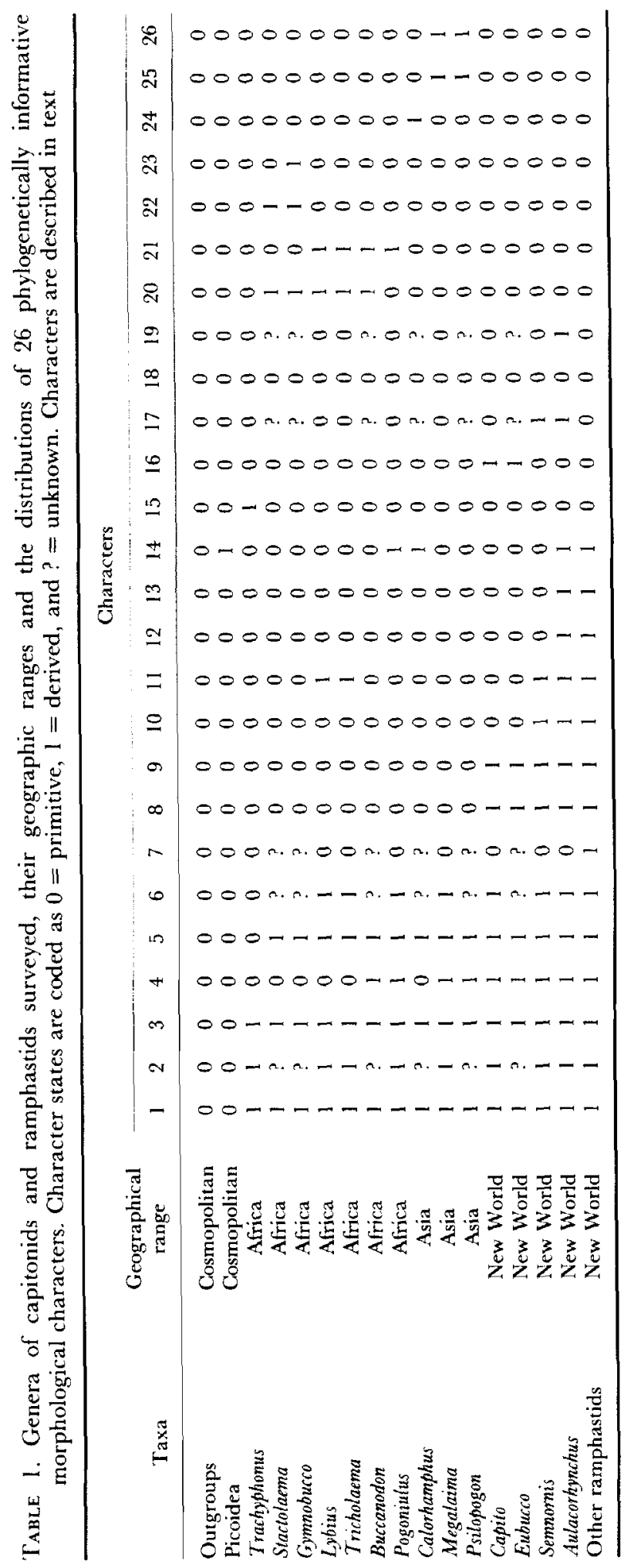




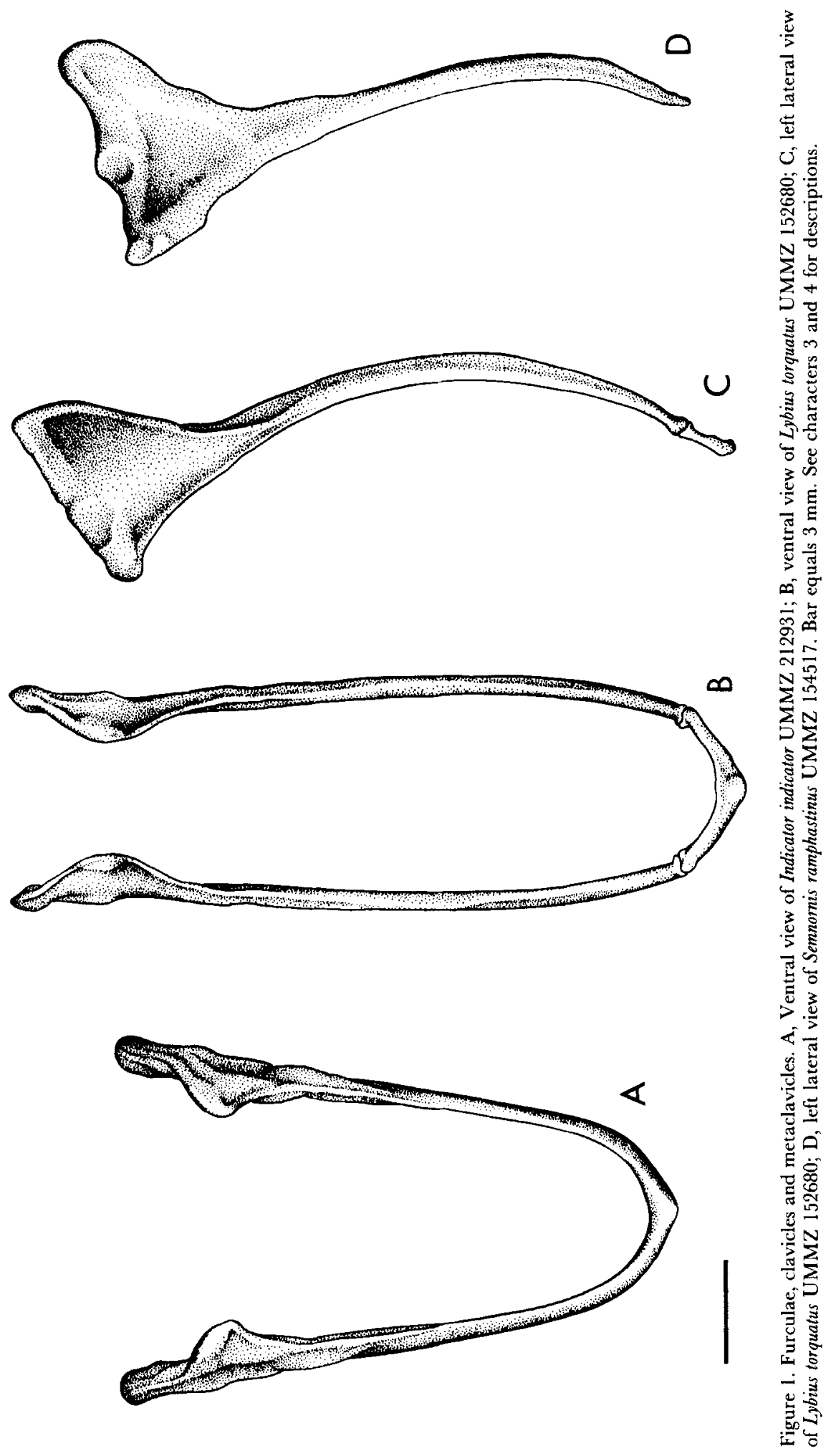


pointed caudally in a V-shape and lacks a distinct hypocleidium. In all other piciforms and most coraciiforms, the clavicles are completely fused; the adult furcula is composed of a single bone which has widened epicleidia and lacks a pronounced hypocleidium (Fig. 1A). These observations agree with those of Verheyen (1955) but are extended to include genera of New World and Old World capitonids which he did not observe.

Both of the character states found in the Ramphastoidea-the three-part furcula and the lack of a complete furcula-are derived with respect to the outgroups, making it difficult to establish a transition series by outgroup comparison alone. Information on the ontogeny of the furcula of the outgroups and other birds may indicate whether the independent, medial bone in the furculae of some capitonids is a novel ossification or the result of a paedomorphic truncation of the ancestral avian ontogenetic sequence of the ossification of the furcula (Alberch, Gould, Oster \& Wake 1979; Fink, 1982).

According to Parker's (1867) original description of the development of the furcula in passerines, Gallus (Galliformes), Phalacocorax (Pelecaniformes), Grus and Turnix (Gruiformes) and Uria (Charadriiformes), the clavicles begin ossifying from two dorsal centres and extend ventrally to meet medially with an "interclavicular process". Unfortunately, it is difficult to discern from Parker's descriptions whether this medial, "interclavicular process" originates from an independent centre of ossification or is produced by the fusion of the two clavicles. Parker (1867) reported that this interclavicular element is not present in picids, psittacids and some other groups which lack a pronounced hypocleidium, implying that the two structures are synonymous. Newton (1899: 858) stated that the hypocleidium often ossifies independently from the two clavicles but he did not give the source for these observations. In contradiction to Parker (1867) and Newton (1899), Knopfli (1919), Lillie (1919) and Romanoff (1960) reported that the furcula of Gallus develops from a dermal membrane which first takes on the characteristic U-shape, and then begins ossifying from two dorsal centres in each clavicle, expanding ventrally and eventually fusing together medially to form the hypocleidium in the absence of an independent interclavicular element. Hillel (1904) and Maillard (1948) observed the same ontogenetic sequence in Eudyptes chrysocome (Spheniscidae) and Catharacta skua (Laridae), respectively. This more recent evidence indicates that the furcula of some non-piciform birds is formed by the fusion of two expanding proximal centres of ossification and not by the fusion of the clavicles to a third, distal-medial centre of ossification. This conclusion contradicts the common statement that the interclavicle bone found primitively in the amniote pectoral girdle is homologous to some element retained in the centre of the avian furcula (e.g. Parker, 1867; Newton, 1899; Romer, 1970).

Newton (1899: 858) also reported that in many species that lack a complete furcula the reduced clavicles are connected by "semi-ossified cartilage or fibrous tissue". Glenny \& Friedmann (1954) reported such a ligamentous connection (Lig. corpus claviculae; Baumel, 1979) running between the greatly reduced clavicles of Mesoenas and Monias (Mesoenatidae), and several unnamed psittacids, while Glenny \& Amadon (1955) did not observe any "interclavicular vestige or pons claviculi" connecting the reduced clavicles of the columbid Otidiphaps. Ligamentous or fibrous connections between the reduced clavicles of these non-piciform birds indicate that this morphological condition results from 
the incomplete or arrested ossification of the dermal membrane precursor of the clavicles, and the lack of a third, independent ossification within the Lig. corpus claviculae in these groups is further evidence that the furculae of many nonpiciforms develop from only two centres of ossification.

In summary, the evidence from the development of the furcula in nonpiciform birds and the anatomy of non-piciforms with incomplete furculae suggests that the independent, medial bone found in the furculae of many capitonids develops from a third, novel centre of ossification. Developmental studies are necessary to determine whether this novel, medio-ventral centre of ossification is more generally distributed in the early ontogentic stages of other piciforms which have completely ossified adult furculae. However, the independent medial bone in the furcula of some capitonids that develops from this ossification centre is a neomorph and will be referred to here as the metaclavicle. The presence of the metaclavicle and reduced clavicles is a synapomorphy of the Ramphastoidea. The incomplete furculae found in ramphastids, New World capitonids, Megalaima, Psilopogon, Buccanodon and Pogoniulus, which lack the metaclavicle appear to be the result of subsequent deletion of this third ossification centre from the ontogeny of the pectoral girdle in these lineages. This conclusion is supported by the observation that the clavicles of all of the Ramphastoidea are similar in their derived shape and proportions (Fig. 1B-D); the presence of a complete furcula is essentially determined by the presence or absence of the metaclavicle.

The clavicles and furculae of the Pici are here hypothesized to have evolved in a transition series from the primitive outgroup state of a fully fused furcula first to (3) a furcula formed by the articulation of reduced clavicles to the metaclavicle, and, subsequently, to (4) the absence of the metaclavicle between the reduced clavicles. Character 3 is hypothesized to be derived in the entire Ramphastoidea and character 4 is hypothesized as derived in Buccanodon, Pogoniulus, Megalaima, Psilopogon, New World capitonids and ramphastids.

(5) In all the ramphastids and capitonids except Trachyphonus, the ectethmoid does not form an osseous bridge to the jugal, while in Trachyphonus, all other piciforms and most coraciiforms the ectethmoid does form a bridge to the jugal (Cracraft, 1968: 346; pers. obs.). The absence of the ectethmoid-jugal bridge is here hypothesized as derived.

(6-7) Swierczewski \& Raikow (1981, character 27) found that the M. flexor perforatus digiti II was absent in all capitonids except Trachyphonus. This flexor was present in Aulacorhynchus, and present but unperforated by the M. flexor hallucis longus in Ramphastos and Pteroglossus (Swierczewksi \& Raikow 1981, character 26). In Trachyphonus and all other piciforms examined, the M. flexor perforatus digiti II was present and perforated by the M. flexor hallucis longus. Swierczewski \& Raikow (1981) hypothesized that the absence of the M. flexor perforatus digiti II is a synapomorphy of a clade containing all capitonids except Trachyphonus, and that the muscle was convergently lost in Aulacorhynchus. They also hypothesized that the unperforated flexor is a synapomorphy of Ramphastos and Pteroglossus and that both derived states evolved from the original perforated state found in the picids, indicatorids and Trachyphonus. By outgroup comparison, both the absence of the M. flexor perforatus digiti II (6) and the presence of an unperforated $M$. flexor perforatus digiti II (7) are derived in the Ramphastoidea. It is not possible to determine which of the two 
possible states (present and perforated, or absent) is primitive to the derived, unperforated M. flexor perforatus digiti II found in Ramphastos and Pteroglossus without further ontogenetic information or some phylogenetic hypothesis. If the Capitonidae were monophyletic, then it would be equally parsimonius to hypothesize either alternative character state as primitive to the unperforated state of Ramphastos and Pteroglossus. However, if the monophyly of the Capitonidae were rejected, then it would be more parsimonious (i.e. require fewer steps) to hypothesize that the unperforated flexor found in Ramphastos and Pteroglossus (7) evolved from the complete absence of the M. flexor perforatus digiti II (6) observed in Aulacorhynchus and other subsequent capitonid outgroups.

(8) Burton (1984: 370-371) found that in Capito, Semnornis and the ramphastids the $M$. psuedotemporalis superficialis pars distalis is bipinnate and has an additional origin by a strong medical slip arising from a prominent bony crista on the posterior orbital wall. A similar but less well-developed state occurs in Trachyphonus (Burton, 1984). In all other piciforms examined, the M. psuedotemporalis superficialis is weakly bipinnate or simple and does not arise from a bony crista on the posterior orbital wall (Burton, 1984). I identified this bony crista independently in the examination of piciform skeletons and found it to be present and well developed in all ramphastids, Capito, Eubucco, and Semnornis. This crista is slightly developed in some Trachyphonus, Slactolaema and Gymnobucco, and undeveloped or absent in all other piciforms and coraciiforms. The bipinnate M. psuedotemporalis pars distalis and the strong bony crista origin on the orbital wall are hypothesized as derived.

(9) Brushy-tipped tongues are found in all ramphastids and New World capitonids; they are not present in any other piciforms (Burton, 1984: 384-385). Brushy-tipped tongues are here hypothesized as derived.

(10) According to Burton (1984: 381) the maxillopalatine attachment of the M. pterygoideus dorsalis lateralis in Semnornis and the ramphastids is made by a well developed dorsal slip with some additional fibres originating from the dorsal surface of the palatal mucosa near the rictus; slight or no palatine attachment of the M. pterogoideus dorsalis lateralis occurs in the picids, indicatorids, and all other capitonids examined. Following Burton (1984), this unique state of the M. pterygoideus dorsalis lateralis is here hypothesized as derived in Semnornis and the ramphastids.

(11) The ramphastids have serrate tomia. The Neotropical capitonid genus Semnornis has a single-toothed tomium. The African capitonids Lybius and Tricholaema have prominent single or double-toothed tomia (Goodwin, 1964; Short \& Horne, 1985). All other piciforms have untoothed or smooth upper mandible margins. The toothed or serrate upper mandibles are here hypothesized as derived.

(12) The large bill of the ramphastids is unique among all birds in shape and internal structure (Owen, 1833). It is the traditional character used to diagnose the ramphastids and has been previously recognized as a synapomorphy of this group (Swierczewski \& Raikow, 1981, character 50).

(13) In the ramphastids, the vomer is short, and abruptly truncate anteriorly and does not articulate to the maxillopalatines (for illustrations see Garrod, 1878; Sclater, 1891). In the capitonids, the vomer is $\mathrm{Y}$-shaped with two stout anterior branches extending anteriorly to meet the maxillopalatines (Fig. 2). In 
the indicatorids and picids, these anterior branches are thin and extend almost the entire length of the palate to fuse with the reduced septo-maxillary splints (Garrod, 1878; Lowe, 1946; personal observation). The truncate, simple vomer used traditionally to diagnose the ramphastids is here hypothesized as derived.

(14) Nearly all capitonids have prominent rictal bristles whereas rictal bristles are absent in ramphastids, picids, indicatorids and the capitonid genera Calorhamphus and Pogoniulus. Swierczewski \& Raikow (1981, character 45) hypothesized that the presence of prominent rictal bristles is a synapomorphy of the Capitonidae. However, prominent rictal bristles are present in the galbulids, bucconids and many coraciiforms, and therefore should be treated as primitive within the Pici. Here, it is hypothesized that the absence of rictal bristles in the Picoidea, the ramphastids, Calorhampus and Pogoniulus is derived.

(15) In the genus Trachyphonus the vomer is uniquely shaped. The caudal portion of the vomer is laterally widened and has a distinct medial ridge running rostro-caudally along its axis and the two processes which extend rostrally to meet with the maxillopalatines are laterally separated at their bases and are orientated in parallel (Fig. 2A). In other piciforms, the caudal portion of the vomer is not as wide and lacks a distinct medial ridge, and the rostral processes of the vomer have a common medial origin and are orientated at an oblique angle to one another (Fig. 2B-E). The exception occurs in ramphastids which lack the rostral arms of the vomer entirely (see character 13). The condition found in Trachyphonus is here hypothesized as derived.

(16) In all Capilo and Eubucco examined, the transpalatine processes of the palatines are well-developed and sharply pointed caudally (Fig. 2E). In all other piciforms, the transpalatine processes of the palatines are not welldeveloped and this region of the palatines is typically smooth or squarely rounded (Fig. 2A-D). The state found in Capito and Eubucco is here hypothesized as derived.

(17) Swierczewski and Raikow (1981, character 20) found the M. iliofemoralis internus absent in Capito maculocoronatus, Semnornis ramphastinus and Aulacorhynchus prasinus, and present in all other piciforms and outgroups examined including other Capito. They hypothesized that the muscle was lost in the ancestor of the former two species and once again in the latter species. If the capitonids are not monophyletic, then the alternative hypothesis that the muscle was lost once and redeveloped in the ancestor of Ramphastos and Pteroglossus requires the same number of evolutionary events. Here, the absence of the M. iliofemoralis internus is hypothesized as derived but it may have arisen independently in each of these taxa.

(18) In Semnornis the tip of the upper mandible fits in the forked tip of the lower mandible, forming a unique forceps-like bill. This morphology is unique among piciforms and is hypothesized as derived.

(19) Swierczewski \& Raikow (1981, character 8) reported that the M. femorotibialis externus pars distalis was absent in all members of the suborder Pici examined except Aulacorhynchus and $7 y n x$, and that this muscle was present in all bucconids, galbulids and other outgroups. They hypothesized that the M. femorotibialis externus pars distalis was lost three separate times and cite this character as an independent synapomorphy of the Indicatoridae, the subfamily Picini, and the Ramphastoidea, with a subsequent reversal in Aulacorhynchus. Without additional assumptions about the evolution of the 

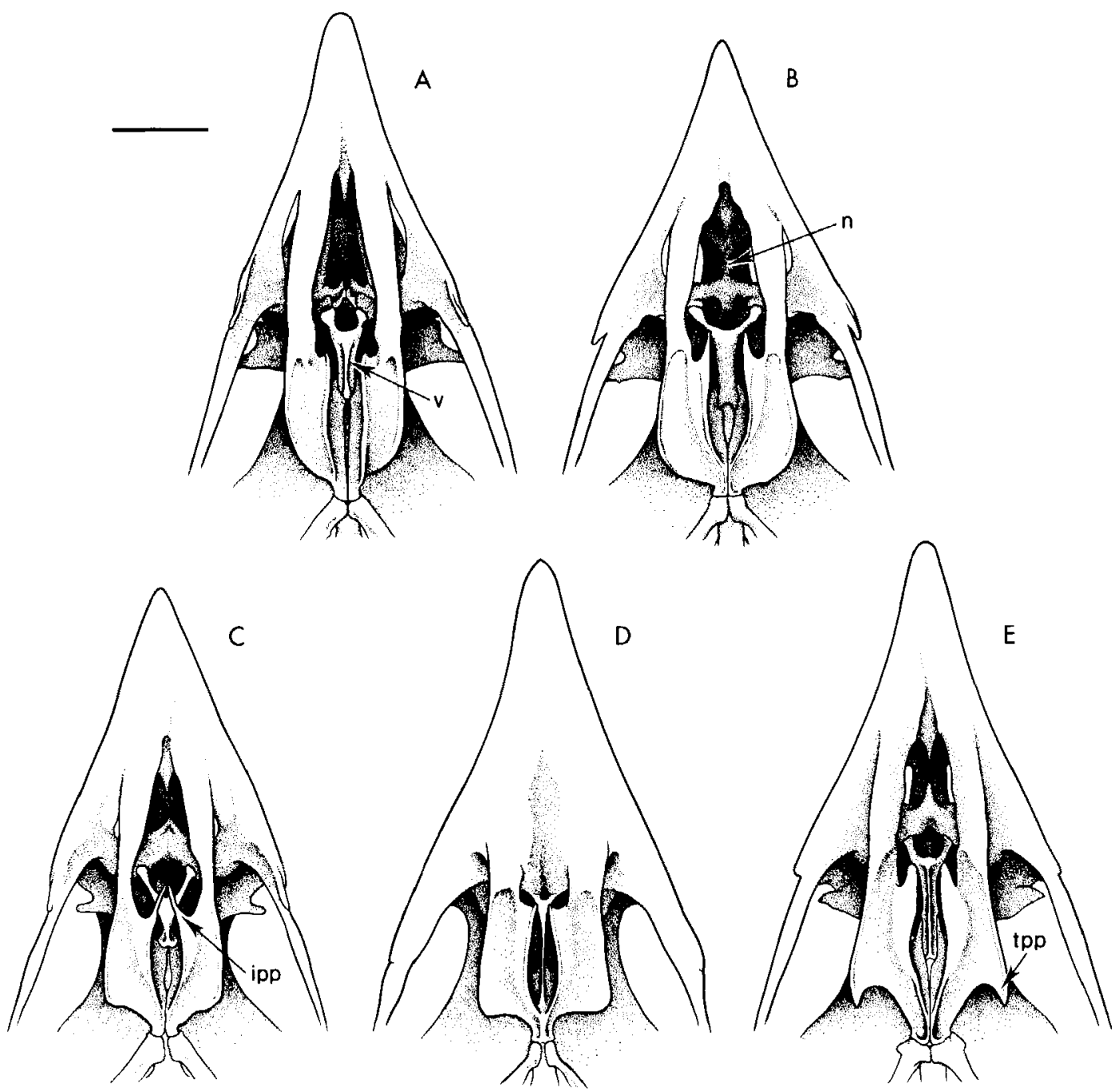

Figure 2. Ventral views of the bony palates of: A, Trachyphonus vaillantii UMMZ 219892; B, Gymnobucco bonapartei UMMZ 208313; C, Lybius vieillotii UMMZ 203869; D, Calorhamphus fuliginosa UMMZ 158280; E, Capito niger UMMZ 216113. Abbreviations: ipp-interpalatine processes, n nasal septum, tpp transpalatine processes, v--vomer. Bar equals $5 \mathrm{~mm}$. Sec characters $15,16,21$, 22 and 24 for descriptions.

muscle, it is more parsimonious to hypothesize a single loss of the M. femorotibialis externus pars distalis in the common ancestor of the suborder Pici with subsequent redevelopments in Aulacorhynchus and Jynx. This alternative hypothesis docs not aflect the final topology of the three but indicates that the loss of the M. femorotibialus externus pars distalis is a synapomorphy of the suborder Pici, and not the Ramphastoidea. Here the reaquisition of the muscle in Aulacorhynchus is hypothesized as derived.

(20) Miller (1915, 1924) reported that the oil glands of all African capitonids, except Pogoniulus and Trachyphonus purpuratus, are unfeathered or "nude", while the oil glands of all other capitonids, ramphastids, indicatorids and most picids 
and coraciiforms are tufted. His observations were independently confirmed by Verheyen (1955). The naked oil gland is here hypothesized as derived within the ramphastoids.

(21) In all species of Lybius, Tricholaema, Buccanodon and Pogoniulus examined, the interpalatine processes of the palatines extend rostro-medially, often meeting with the vomer in the centre of the palate (Fig. 2C). In other capitonids and ramphastids, the interpalatine processes are not particularly elongate and do not articulate to the vomer (Fig. 2A-B, D-E). The elongated anterio-medially orientated interpalatine processes which often articulate to the vomer in the centre of the palate in Lybius, Tricholaema, Buccanodon and Pogoniulus are unique among the Piciformes and Coraciiformes, and are here hypothesized as derived.

(22) In Stactolaema and Gymnobucco, the bony nasal septum running caudally from the premaxilla to the rostral articulation with the vomer and then laterally to the maxillopalatines is highly pneumatisized and 'tubular' (Fig. 2B). In all other piciforms, this bony nasal septum is not highly pneumatisized or 'tubular' in appearance and it is often absent (Fig. 2A, C-E). The former condition is here hypothesized as derived.

(23) In Gymnobucco, the rictal bristles are arranged in prominent, vertical tufts on either side of the base of the culmen. This feature is unique within the piciforms (Goodwin, 1964; Short \& Horne, 1985) and is here hypothesized as derived.

(24) In Calorhamphus, the maxillopalatines are completely fused medially for the entire length of the palate rostral to the palatines (Fig. 2D). This degree and type of fusion is unique among the piciforms and most of the outgroups, and is here hypothesized as derived.

(25) All specimens of the capitonid genera Psilopogon and Megalaima examined here have a prominent ridge running rostro-caudally between the orbitals on the outer surface of the fused frontal bones. This condition is unique among the piciforms and is here hypothesized as derived.

(26) Burton (1984: 355) observed that some species of Megalaima have a distinct lateral shelf on the medial condyle of the quadrate "to provide some measure of kinetic coupling' with the mandible. All specimens of Megalaima and Psilopogon examined here possessed this shelf-like projection on the medial condyle. This condition is unique among the piciforms and outgroups, and is here hypothesized as derived.

\section{Primitive or equivocal characters (27-32)}

(27) Simpson \& Cracraft (1981, character 11) reported that in ramphastids and capitonids there are two, smooth bony canals in the proximal end of the tarso-metatarsus: a smaller, anterior canal, that encloses the flexor hallucis longus, and a larger, posterior canal, that encloses the other four flexor tendons. In indicatorids and picids, the posterior or plantar canal has indentations in its sides (Simpson \& Cracraft, 1981) or is divided by a complete osseous bridge or bridges (personal observation) to form a third partial or complete plantar canal which encloses the flexor perforans et perforatus digiti III (for illustration see Simpson \& Cracraft, 1981: fig. 6). In the Galbulidae, Bucconidae and the Coraciiformes, the flexor tendons pass through an open groove in the proximal end of the tarsometatarsus and not through osseous canals, making it impossible 
to establish the polarity of the character within the Pici by outgroup comparison. Despite the uniformity in position and shape of the hypotarsal canals in capitonids and ramphastids cited by Simpson \& Cracraft (1981) as the basis for identifying this character state as derived, it is equally possible that the more detailed and specialized hypotarsal canals of the indicatorid and picids are the derived state making the character a synapomorphy of the Picoidea. Embryological evidence on the ontogeny of the hypotarsal canals would help determine whether the state found in indicatorids and picids develops through a terminal addition to the ontogenetic sequence of the more general and simple state found in capitonids and ramphastids. Without such additional evidence to order this transition series, it is not possible to assign the polarity of this character confidently and it should not be considered a synapomorphy of the Ramphastoidea.

(28) Parker (1875) first described the palate of a barbet, Megalaima asialica. Following these observations, Parker (1875), Garrod (1878), Seebohm (1890) and Beddard (1898) characterized the barbets as "aegithognathous with a desmognathous tendency". This general description was restated by Ridgway (1914), Lowe (1946) and Burton (1984), while Verheyen (1955) described capitonids as desmognathous. Simpson \& Cracraft (1981) hypothesized the maxillopalatine fusion or articulation to the nasal septum in the Capitonidae, Ramphastidae, Galbulae and Coraciiformes as primitive to the derived, unfused maxillopalatines found in Indicatoridae and Picidae. Despite the repeated references to aegithognathy in some of the Captonidae, my observations (Fig. 2) are compatible with the conclusions of Verheyen (1955) and Simpson \& Cracraft (1981) that the maxillopalatines articulate or fuse in the centre of the palate to some degree in all capitonids and ramphastids, and that the aegithognathous ("saurognathous" of Parker, 1875) palates of the Indicatoridae and Picidae are likely to be derived. The terms "partially desmognathous" and "aegithognathous with a desmognathous tendency" used in traditional diagnoses of the Capitonidae do not describe a shared derived character and are not evidence of capitonid monophyly.

(29) Forbes (1882), Beddard (1898), Ridgway (1914) and others reported that both the capitonids and ramphastids have long, "intestiniform" gall bladders and cited this character as evidence of close relationship between the two families. Forbes (1882) also pointed out that this type of gall bladder is found in picids and indicatorids as well. The intestiniform gall bladder is apparently a synapomorphy of the Pici and not a shared derived character of the capitonids and ramphastids.

(30) Glenny $(1944,1955)$ documented variations in the morphology of the major arteries in the region of the heart of piciformes. However, none of the variations he identified appear to be phylogenetically informative within the Ramphastoidea.

(31) Nitzsch (1840, 1867), Garrod (1878), Beddard (1896), Lowe (1946) and Verheyen (1955) described variations in the pterylosis of piciforms. While some potentially informative variations of the spinal and other tracts among the piciforms have been identified, the observations of the different authors are sometimes contradictory. With additional observations, some pterylogical characters may prove to be informative in diagnosing clades within large genera such as Megalaima and Pogoniulus (Verheyen, 1955: 5-6). 
(32) Berlioz (1936) first described the unusual nostril morphology found in some capitonids and ramphastids. Primitively within the piciform and nonpiciform birds, the nasal fossae are single, oval depressions in the dorsal surface of the upper mandible. In some capitonids and all ramphastids, the single oval depression is divided by a transverse lamina of bone forming separate rostral and caudal apertures leading into the nasal cavity. This condition is further derived in ramphastids (Prum, 1982). Among the species examined here, the double nostril apertures are present in all specimens of ramphastids, Semnornis, Megalaima, Psilopogon, Calorhamphus, Pogoniulus, Buccanodon and Stactolaema, and in some Trachyphonus, Gymnobucco and Tricholaema. This condition is absent in all the outgroups, all Capito, Eubucco and Lybius, and some Trachyphonus, Gymnobucco and Tricholaema. The variation among and within genera in the detailed morphology of the lamina dividing the nasal fossae is so great that it is difficult to be confident that the structures in various genera are homologous. Ontogenetic information on the origin of this morphology and further detailed investigation of this character may yield some interesting phylogenetic hypotheses.

\section{RESULTS}

\section{Comparisons of allernative phylogenetic hypotheses}

Four alternative phylogenetic hypotheses were compared: (1) the most parsimonious or minimum length phylogeny; (2) the most parsimonious phylogeny in which the capitonids and ramphastids are monophyletic sister groups; (3) the first DNA-DNA hybridization phylogeny (Sibley \& Ahlquist, 1985), in which the New World capitonids and ramphastids are monophyletic sister groups and the Old World capitonids are the sister group to the New World ramphastoids and the Picoidea; and (4) the revised DNA-DNA hybridization phylogeny (Sibley \& Ahlquist, 1986) in which the Old World capitonids are the sister group to the ramphastids and the monophyletic New World capitonids. In the first analysis, all taxa and 26 informative characters were included and four strict-consensus trees based on the most parsimonious resolutions of each of the four alternative hypothesis were identified (Fig. 3).

The most parsimonius phylogenetic hypothesis requires 33 changes of the 26 characters (Consistency Index or $\mathrm{CI}=0.79$, Fig. $3 \mathrm{~A}$ ). In the strict-consensus tree of these phylogenies, the New World capitonids and ramphastids comprise a clade, but neither the New World capitonids nor the Old World capitonids are monophyletic groups (Fig. 3A). The most parsimonious phylogenies in which the capitonids and ramphastids were assumed to be monophyletic sister groups require 41 character state changes $(\mathrm{CI}=0.63$, Fig. 3B). The first DNA-DNA hybridization phylogeny (Sibley \& Ahlquist, 1985) requires 41 character changes $(\mathrm{CI}=0.63$, Fig. $3 \mathrm{C})$, while the second DNA-DNA hybridization phylogeny (Sibley \& Ahlquist, 1986) requires 38 steps $(\mathrm{CI}=0.68)$ the account for the observed character states (Fig. 3D). The relationships among the Old World capitonids excluding Trachyphonus remain unresolved in each of the four alternative hypotheses.

Since character changes cannot be compared among consensus trees, a second analysis was performed in order to investigate the different hypotheses for the 


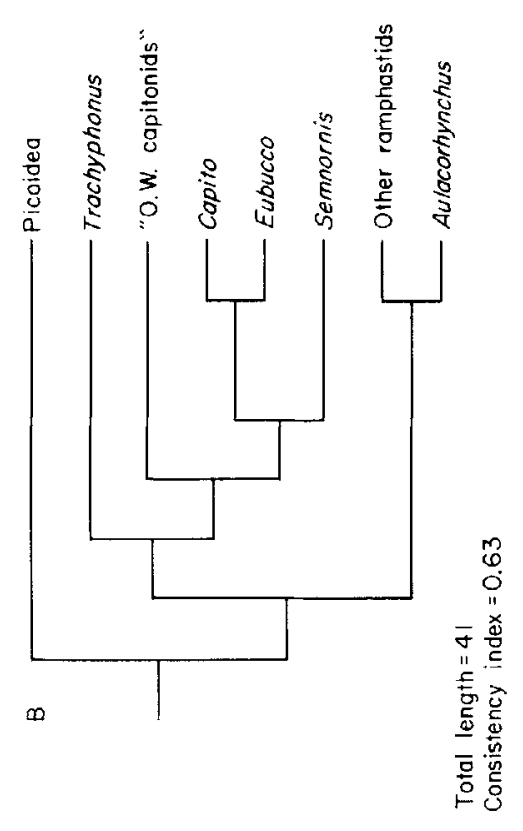

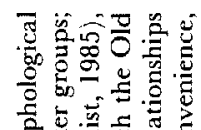

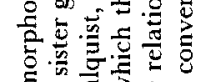

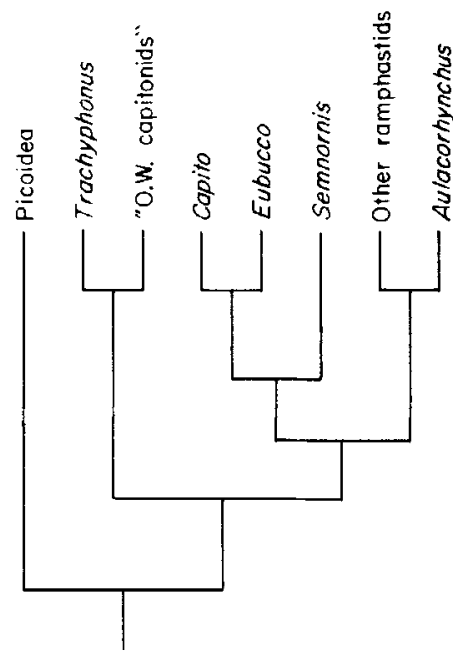

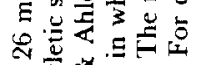

s

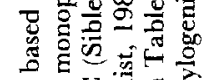

的记

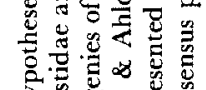

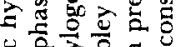

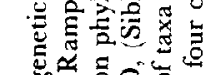

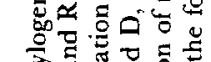

0

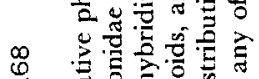

品

o

资

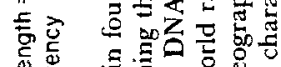

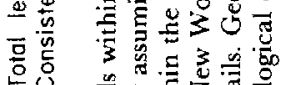

응

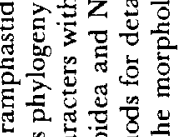
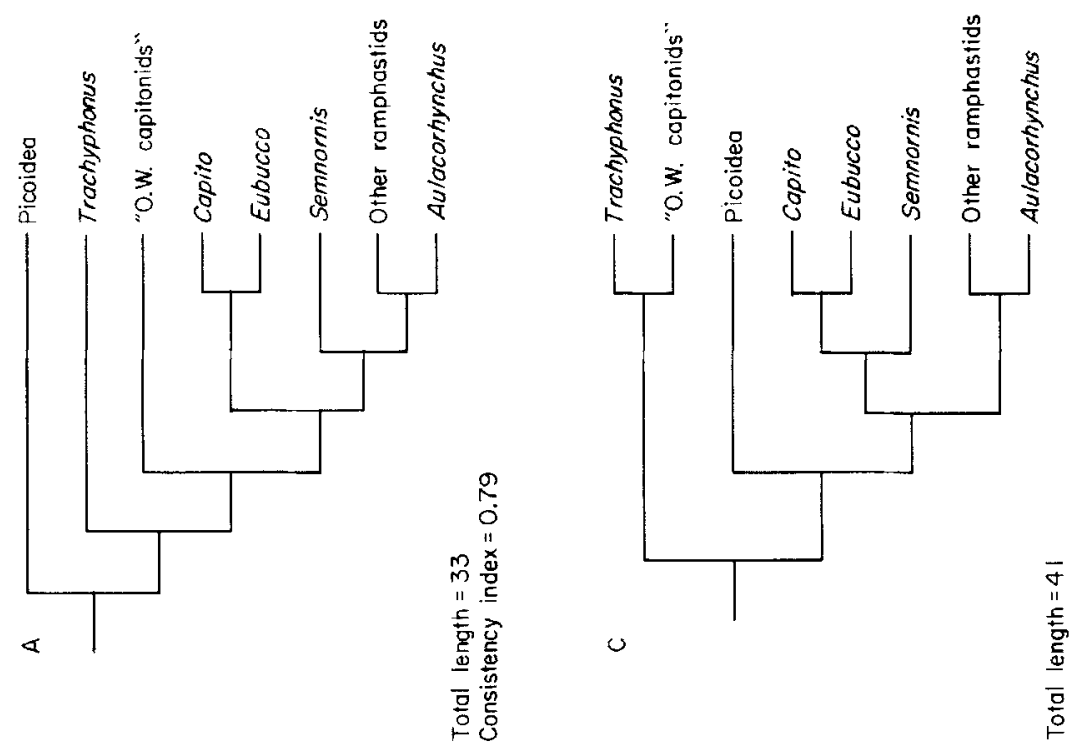

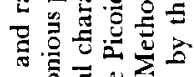

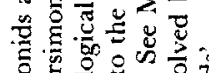

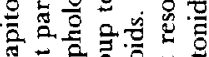

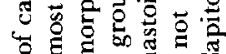

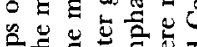

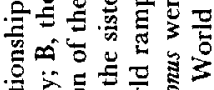

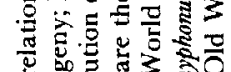

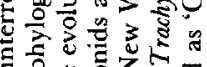

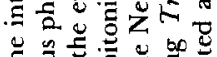

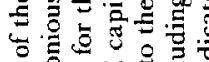

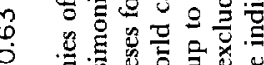

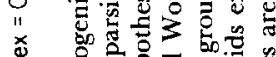

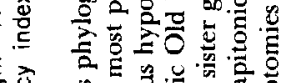

等

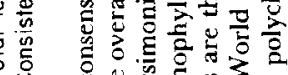

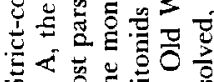

के

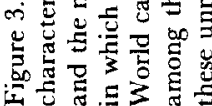


evolution of the morphological characters within the major branches of the four phylogenetic hypotheses. In this analysis, the same four phylogenetic hypotheses were compared, but the Old World capitonids excluding Trachyphonus were assumed to be monophyletic and characters 20-26, which pertain only to the relationships among genera in this group, were not included. For each alternative hypothesis, a single fully resolved phylogeny was obtained. Each of these phylogenies is congruent with the resolved branches of the corresponding strict-consensus tree in the first analysis. These four trees are illustrated with the diagnostic changes of characters 1-19 superimposed on each lineage (Fig. 4). The most parsimonius phylogeny requires 21 changes of 19 characters $(\mathrm{CI}=0.90 \mathrm{~g} \mathrm{Fig.} \mathrm{4A}$, while the phylogeny assuming the monophyly of the capitonids requires 28 character evolutions $(\mathrm{CI}=0.68$, Fig. $4 \mathrm{~B})$. The first DNA-DNA hybridization phylogeny (Sibley \& Ahlquist, 1985) requires 28 changes $(\mathrm{CI}=0.68)$ to account for all the observed characters (Fig. 4C), while the second (Sibley \& Ahlquist, 1986) requires 25 evolutionary events $(\mathrm{CI}=0.76$, Fig. 4D).

Each of the previously proposed alternative phylogenies of the Ramphastoidea requires a greater number of character state changes than the most parsimonious phylogeny, and each requires the recognition of a greater number of lineages that are not diagnosed by any recognized morphological synapomorphies. These results strongly support the hypothesis that the traditionally defined Capitonidae is paraphyletic. The Neotropical capitonids and ramphastids comprise a well supported monophyletic group within the pantropical radiation of the ramphastoids. Neither the Old World nor the New World capitonids share any derived morphological character states, indicating that either is a monophyletic group; rather both geographic assemblages appear to be composed of clades which share varying amounts of common ancestry with the ramphastids. All the ramphastoids excluding the African genus Trachyphonus form a corroborated clade. The relationships among the Old World capitonids excluding Trachyphonus are not completely resolved by the morphological characters analysed here. The sister group to the New World capitonids and ramphastids appears to be either a clade comprised of all Old World capitonids excluding Trachyphonus or the Asian genera Megalaima and Psilopogon. The sister group to the ramphastids themselves is the genus Semnornis.

\section{Diagnosis of the Ramphastoidea}

Although the monophyly of the Ramphastoidea was assumed a priori in this investigation, a revised set of diagnostic synapomorphies was identified. Swierczewski \& Raikow (1981) hypothesized that the absence of the M. femorotibialus externus pars distalis (character 19) was a synapomorphy of the Ramphastoidea. However, their observations indicate that this derived morphology is generally distributed throughout the picids and indicatorids, as well, and is likely to be an additional synapomorphy of the entire Pici (Piciformes sensu stricto). Simpson \& Cracraft (1981) hypothesized that the Ramphastoidea have a derived condition of the hypotarsal canals (character 27); however, in the absence of a similar outgroup character state, it is difficult to conclude confidently whether the ramphastoid condition is derived or primitive within the Pici. In the absence of further ontogenetic information, 


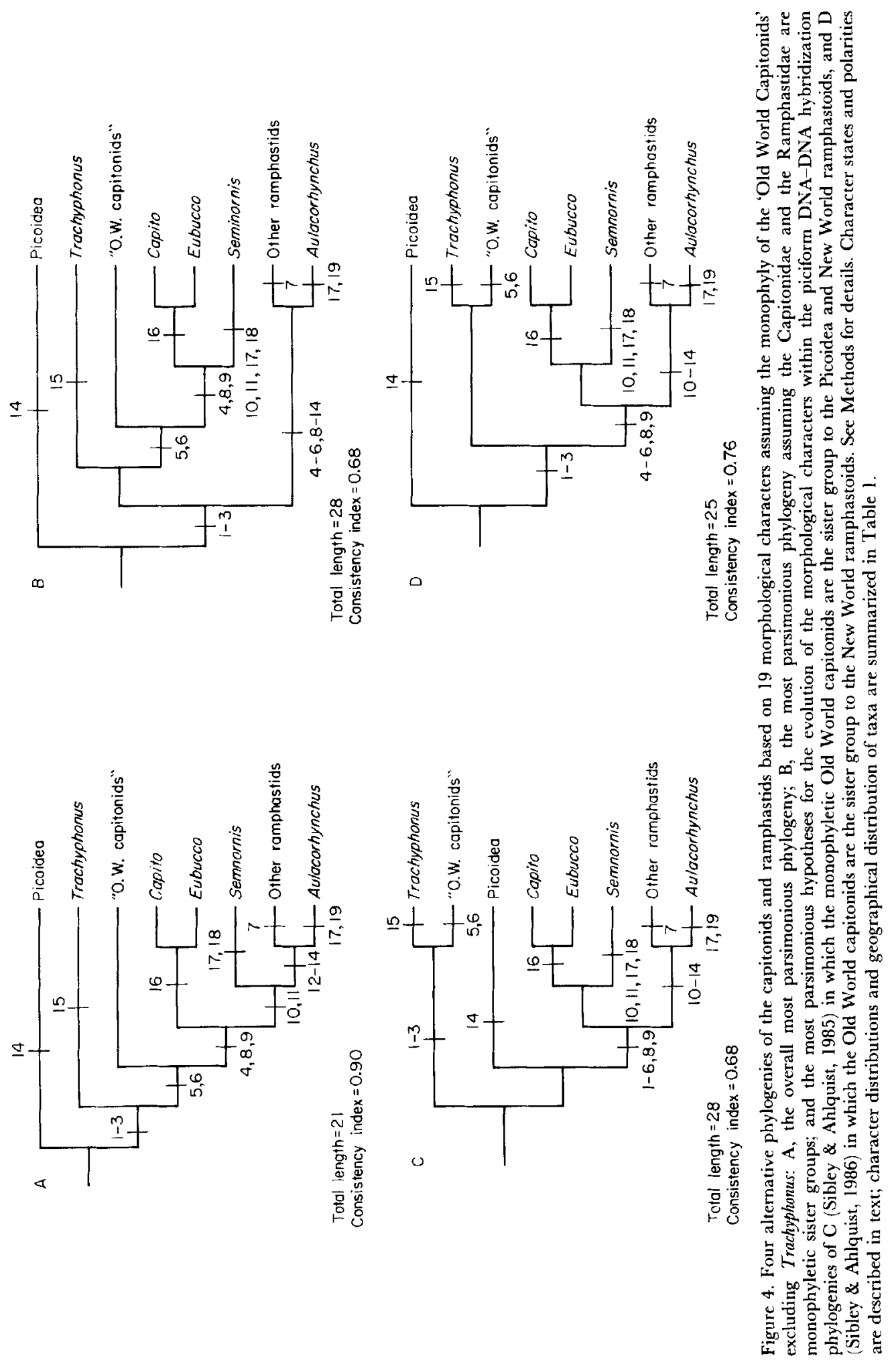


this character is excluded from the diagnosis of the Ramphastoidea. The monophyly of the Ramphastoidea is supported by three derived morphological character states: (1) the absence of the post-orbital ligament (Burton, 1984), (2) presence of a tendious slip from the $\mathrm{M}$. extensor digitorum longus to digit IV (Swierczewski \& Raikow, 1981) and (3) the presence of reduced clavicles and, primitively within the Ramphastoidea, a metaclavicle bone which forms the ventral portion of the furcula.

\section{Diagnoses of clades within the Ramphastoidea}

The monophyly of the Capitonidae as traditionally defined was not supported by any morphological synapomorphies. The only character previously hypothesized as a synapomorphy of the Capitonidae, (14) the presence of rictal bristles (Swierczewski \& Raikow, 1981), was found by outgroup comparison to be primitive within the Pici. None of the three geographic assemblages of capitonids-African, Asian or New World-possesed any shared derived morphological characters supporting their monophyly.

Although the relationships among the Old World capitonids were not completely resolved by this data set and remain equivocal, one resolution of ramphastoid phylogeny is proposed here as a preliminary hypothesis (Fig. 5). It is the most parsimonious phylogeny in which the African capitonids excluding Trachyphonus are assumed to be monophyletic. This resolved phylogeny is the basis for the classification and diagnoses presented below. It should be noted that this resolution is not objectively better than many other alternatives, given the present data, but it is proposed here as a highly plausible, heuristic prediction. Any additional synapomorphies of the African capitonids exclusive of Trachyphonus would make it the most parsimonious overall resolution. Increased confidence may be placed on the diagnoses of clades which are resolved in the most parsimonious consensus tree (Fig. 3A).

Two morphological synapomorphies support the monophyly of a clade including all the capitonids and ramphastids excluding Trachyphonus, the genus of African ground barbets: (5) lack of an osseous ectethmoid-jugal bridge and (6) absence of the M. flexor perforatus digitii II (which subsequently reappears unperforated in Ramphastos and Pteroglossus) (Swierczewski \& Raikow, 1981). The monophyly of the sister group of this clade, the genus Trachyphonus, is supported by the derived shape of the vomer (character 15) and many other derived plumage characters not discussed here (Short \& Horne, 1980, 1985). Within Trachyphonus, the monophyly of a clade containing all species except $T$. purpuratus is supported by (20) the presence of a nude oil gland and the behaviour of nesting in burrows in the ground (Short \& Horne, 1980, 1985).

The clade containing all New World ramphastoids is supported by at least two morphological synapomorphies: (8) the additional origin of the M. psuedotemporalis superficialis pars distalis on a well developed bony crista on the posterior wall of the orbit (Burton, 1984; personal observation) and (9) the presence of a brushy-tipped tongue (Burton, 1984).

All ramphastids and New World capitonids also share (4) the loss of the metaclavicle resulting in an incomplete furcula. However, this derived character state also occurs in the Asian capitonid genera Megalaima and Psilopogon, and in the African capitonid genera Pogoniulus and Buccanodon. If the African capitonids 


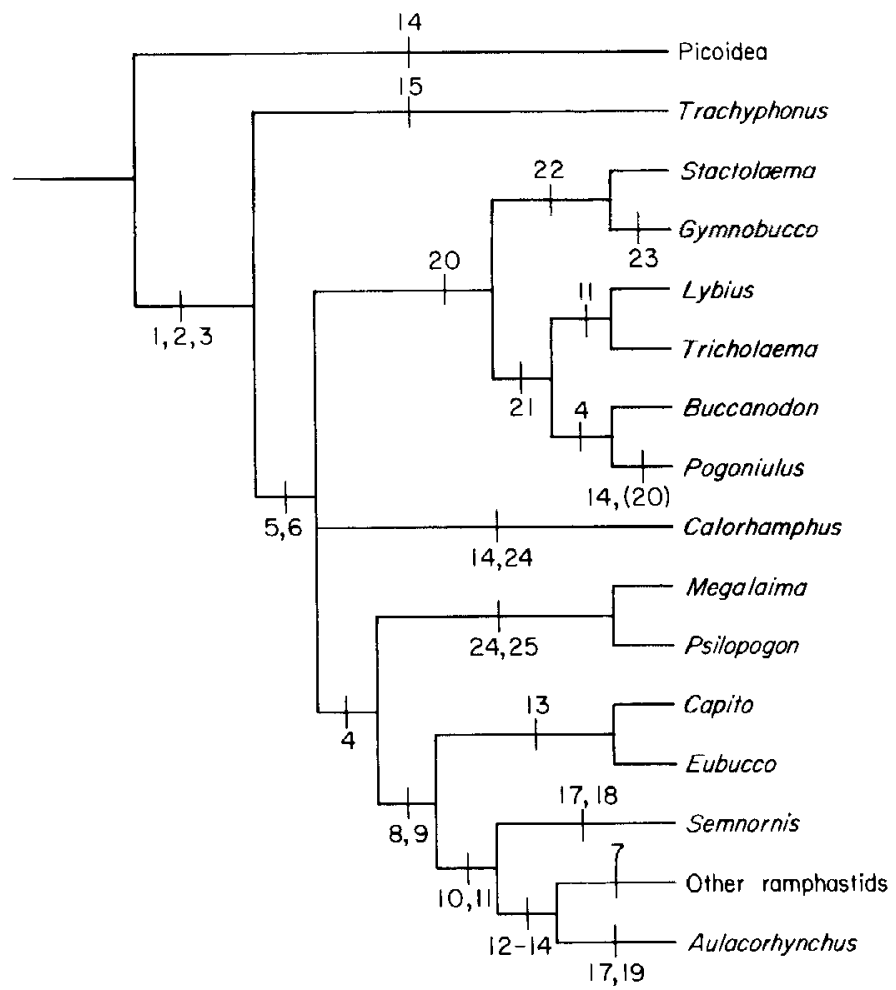

Figure 5. Proposed resolution of the phylogeny of the capitunids and ramphastids with the hypothetical transitions of 26 morphological characters. Character reversals are indicated in parentheses. Character states and polarities are described in text and character distributions are summarized in Table 1. This phylogeny is the most parsimonious resolution of the morphological characters assuming the monophyly of the African capitonids excluding Trachyphonus. The relationships of the genus Calorhampus are unresolved.

excluding Trachyphonus are monophlyletic (see diagnosis below), then the most parsimonious hypothesis is that the loss of the metaclavicle occurred once in the common ancestor of Pogoniulus and Buccanondon and once in an exclusive common ancestor of Megalaima, Psilopogon and the New World ramphastoids.

The clade comprised of Capito and Eubucco is supported by (16) the presence of derived transpalatine processes. The clade comprised of Semnornis and the ramphastids is supported by (10) a unique form of attachment of the M. pterogoideus dorsalis lateralis to the maxillopalatine (Burton, 1984) and (11) toothed or serrate tomia (which also occurs in Lybius and Tricholaema). The absence of the M. iliofemoralis internus (17) occurs in Capito maculocoronalus, Semnornis and Aulacorhynchus (Sweirczewski \& Raikow, 1981) implying that they may form a clade. However, it is as parsimonious to hypothesize three independent losses of this muscle as any other combination of losses and redevelopments, so this character is completely uniformative at present.

Ramphastid monophyly is well supported by many shared derived characters (e.g. characters 12, 13, 14). Variation in the characters treated here imply that Aulacorhynchus is the sister group to the rest of the ramphastids, or at least to Ramphastos and Pteroglossus (Swierczewski \& Raikow, 1981). 
The monophyly of the African capitonids excluding Trachyphonus is supported by (20) the presence of an untufted or 'nude' uropygial gland (which has been subsequently reversed in Pogoniulus and been convergently lost in the Trachyphonus vaillantii clade) (Miller, 1915, 1924; Verheyen, 1955). The monophyly of the clade containing Pogoniulus, Buccanodon, Tricholaema and Lybius is supported by (21) the presence of uniquely shaped interpalatine processes. The monophyly of Stactolaema and Gymnobucco is supported by (22) a unique bony palate morphology and the monophyly of Gymnobucco is supported by (23) the presence of uniquely tufted rictal bristles. The clade including Buccanodon and Pogoniulus is supported by (4) the loss of the metaclavicle, while Pogoniulus, excluding Buccanodon duchaillui, may be diagnosed by (20) the reaquisition of the tufted oil gland. The clade comparised of Lybius and Tricholeama is supported by (11) the toothed upper mandible. The monophyly of each of the genera Stactolaema, Lybius and Tricholaema is not yet substantiated by derived morphological characters.

The clade containing Megalaima and Psilopogon is supported by (25) the presence of a ridge running rostro-caudally on the surface of the skull between the orbits and (26) the presence of a prominent shelf on the medial condyle of the quadrate (Burton, 1984). The monophyly of the genus Megalaima (sensu Peters, 1948) has yet to be supported. No derived characters implying more recent common ancestry between Calorhamphus and any other genera of capitonids excluding Trachyphonus were found, but one osteological autapomorphy of this monotypic genus was identified (character 24).

\section{DISCUSSION}

\section{Alternative phylogenies of the Ramphastoidea}

The monophyly of the New World capitonids and ramphastids originally proposed by Burton (1984) is also supported by DNA-DNA hybridization (Sibley \& Ahlquist, 1985, 1986). Although this detail remained consistent, Sibley \& Ahlquist $(1985,1986)$ proposed two otherwise very different hypotheses for the interrelationships among ramphastoids. Sibley \& Ahlquist (1985) hypothesized that the Old World capitonids are the sister group to the New World ramphastoids and the Picoidea and that the date of the divergence of these two lineages was $c .78 \mathrm{~m} . \mathrm{y}$. BP. This hypothesis is completely unsupported by the morphological data presented here. No morphological synapomorphies of the group including New World capitonids, ramphastids, picids and indicatorids were found, and the phylogenetic hypothesis in which their monophyly was assumed required many more character changes than the most parsimonious tree (Figs $3 \mathrm{~A}, \mathrm{C}, 4 \mathrm{~A}, \mathrm{C}$ ).

In a revised phylogeny of the Piciformes (sensu stricto), Sibley \& Ahlquist (1986) hypothesized that the Old World capitonids are the sister group to the New World capitonids and ramphastids and that the divergence date between the New and Old World lineages was c. 55 m.y. BP. Although the revised DNA-DNA hybridization phylogeny appears to be partially incongruent with the morphological phylogeny presented here (Figs 3A, D, 4A, D, 5), the two phylogenies are actually congruent with one another since Sibley \& Ahlquist (1985, 1986) did not include Trachyphonus, Calorhamphus or Semnornis in their 
analyses (C. G. Sibley, personal communication). Sibley \& Ahlquist (1986) generalized from their sample of New and Old World capitonids to conclude that each of these geographic assemblages is monophyletic. More conservatively, Sibley \& Ahlquist's (1986; G. G. Sibley, personal communication) data indicate that the Old World and New World capitonids excluding Trachyphonus, Calorhampus and Semnornis are each monophyletic. This conclusion is completely congruent with the consensus three based on the most parsimonious resolutions of the morphological data presented here (Fig. 3A).

Such striking congruence between different data sets should lead to increased confidence in the common conclusions of both investigations. However, the lack of original data substantiating either of the DNA-DNA hybridization hypotheses raises questions about the justification of the major differences between them. The differences between the revised phylogeny and the original hypothesis are due to increases in sample size and added allowances for variation in average genomic rate, which are correlated with age at first maturity (C. G. Sibley, personal communication). The nearly $25 \%$ reduction in DNA-DNA hybridization distances between New and Old World ramphastoids cannot be due to the variation in age at first maturity between these taxa because this is not known to vary at all within the group. If this $25 \%$ reduction in distance was produced solely by the addition of new data, and not through the elimination of some data, then the variation among these distances must be tremendous, indicating major problems in the data set. While it is completely valid to revise scientific hypotheses on the basis of new evidence, it is impossible to evaluate the confidence of revisions for which the original data are not presented. Other comparisons of morphological and DNA-DNA hybridization phylogenies have identified both congruence and conflict (e.g. Lanyon, 1985; McKitrick, 1985; Sibley \& Ahlquist, 1983, 1986). The degree of congruence between morphology and the revised DNA-DNA hybridization phylogeny of the ramphastoids is certainly among the greatest yet identified for these two types of data for any avian group.

The New World genera Capito and Eubucco have been generally regarded as very closely related (Sclater, 1861; Ripley, 1945; Goodwin, 1964; Short, 1985). Sclater (1861, 1891) and Ripley (1945) lumped both into the genus Capito. Capito and Eubucco are here found to form a clade, but the monophyly of each genus has yet to be supported explicity. The monophyly of Semnornis has long been recognized on the basis of this unique bill morphology (18). The morphological evidence that Semnornis is the sister group to the ramphastids confirms Sclater's (1861: 183) observation of a "very considerable rapprochement" between them.

Berlioz (1936), Ripley (1945), Goodwin (1964) and Wolters (1976) proposed some interrelationships among Old World capitonid genera. Recently, Short \& Horne (1985) and Short (1985) analysed various aspects of the radiation and speciation of African capitonids, and they proposed a classification of the African capitonids based on ecological and behavioural affinities among genera. All previous authors have treated the African and Asian capitonids as monophyletic groups, with the exception of Swierzcewski \& Raikow (1981) who proposed that Trachyphonus is the sister group to the rest of the capitonids. Although the relationships among the Old World capitonid genera are not completely resolved by these morphological characters, no morphological synapomorphies 
of either the African or Asian capitonids were identified. The African capitonids excluding Trachyphonus probably comprise a clade, as Goodwin (1964) implied. The groups composed of the African genera Stactolaema and Gymnobucco, Lybius and Tricholaema, and Pogoniulus and Buccanondon were previously proposed by Goodwin (1964) and Short \& Horne (1985), and their monophyly is supported here by morphological synapomorphies.

The group composed of Asian genera Megalaima and Psilopogon was recognized by Berlioz (1936), Goodwin (1964) and Wolters (1976) on general plumage similarity and is further corroborated here by two osteological synapomorphies. The loss of the metaclavicle (4) in these two Asian genera suggests that they may share a most recent common ancestor with the New World capitonids and ramphastids. This is the most parsimonious hypothesis if the African capitonids excluding Trachyphonus are monophyletic. This preliminary hypothesis is anecdotally supported by the additional general similarities in size and nostril morphology (32) of some of these species, and should be interesting to pursue in future investigations. The relationships of Calorhamphus to other Old World capitonids excluding Trachyphonus remains unknown and its position within the capitonids is completely enigmatic.

The morphological phylogeny proposed here implies that some of the behavioural similarities among capitonid genera which have been used to support systematic hypotheses are convergent. For example, Ripley (1945) hypothesized that the coloniality of Gymnobucco and Calorhamphus "forms a link" between the African and Asian radiations of capitonids whereas the morphological data do not indicate any specific phylogenetic relationship between these two genera. Short \& Horne (1985) suggested that similarities in duetting behaviour and song structure between Trachyphonus and the Lybius bidentatus species-group implied systematic affinity between them, whereas this morphological phylogeny places these two groups in very different positions within the capitonid radiation, suggesting that their behavioural similarities are convergent.

\section{Palaeontology and biogeography of the Ramphastoidea}

The fossil record of the Ramphastoidea is generally poor (Brodkorb, 1971; Olson, 1985). Ballman (1969a, 1969b, 1983) described three species and the new genus Capilonides from the early Miocene of Bavaria, the late Miocene of France and the middle Miocene of southern Germany, and he assigned the genus to the Capitonidae. Olson (1985) also reported that yet undescribed fossil capitonids have been found among material from the early Miocene of central Florida.

Ballman (1983) used the overall size and proportions, and a number of specific characters of the humerus, carpometacarpus and tarsometatarsus of the Capitonides material from southern Germany, to conclude that Capitonides is closely related to Trachyphonus within the Capitonidae. Based on osteological synapomorphies recognized here and in the literature, Capitonides can be unambigously placed within the Pici (Piciformes sensu stricto). Ballman (1983) described the deep lateral hypotarsal groove for the tendon of the $\mathrm{M}$. flexor hallucis longus in the tarsometatarsus of Capitonides, and Simpson \& Cracraft (1981) recognized this character as a synapomorphy of the extant Pici. However, all extant Pici also share the derived novelty of two separate 
hypotarsal canals in the distal tarsometatarsus (Simpson \& Cracraft, 1981). As figured in Ballman (1983), Capitonides has a single, undivided hypotarsal canal, indicating that it is not within the clade including all the extant Pici. If the hypotarsal region of the Capitonides material is damaged and it is demonstrated that Capitonides has divided hypotarsal canals as in the extant Ramphastoidea, its relationships will still be equivocal since this condition of the hypotarsal canals is likely to be primitive within the Pici and not a synapomorphy of the Ramphastoidea (see character 27).

Other characters cited by Ballman (1983) as indicative of relationship between Capitonides, the Capitonidae, in general, and Trachyphonus, in particular, are either primitive by his own observation (Ballman, 1983:47) or so variable in distribution and expression among the extant Pici as to be uniformative (personal observation). Ballman's (1983) comparison of the size and proportions of the Capitonides material and to single specimens of 11 extant species of capitonids is not statistically significant and cannot be considered as credible evidence of relationship between Capitonides and Trachyphonus. Unfortunately, the only recognized osteological synapomorphy of the Ramphastoidea, (3) the presence of reduced clavicles and the metaclavicle, has not been preserved in the Capitonides specimens and would seem to be a particularly fragile character. At present, Capitonides is most parsimoniously placed as the sister group to the extant Pici since it apparently lacks one of the derived character states which diagnoses that clade.

Ballman (1983) hypothesized that the presence of Capitonides in central Europe constituted a range extension for the Capitonidae and indicated that the climate of Miocene Europe was milder than present. Such palacoclimatic speculation is unsupportable since the evidence indicates that Capitonides diverged from the Pici before the cosmopolitan Picoidea diverged from the pantropical Ramphastoidea. Even if Capilonides is a member of the Ramphastoidea it is just as plausible to speculate that it had different ecological tolerances from the extant ramphastoids. This discussion is not meant to imply that the historical range of the Ramphastoidea could not have been larger than at present but rather that, given the present material, Capitonides cannot be used as evidence for such a range extension.

Ripley (1945) suggested that the capitonids, exluding the ramphastids, originated in Asia and that two lineages dispersed to and diversified in Africa and the New World. Further speculation on the biogeographic history of the capitonids and ramphastids has been hampered by the recognition of a paraphyletic Capitonidae excluding the ramphastids and by the assumption of monophyly of each of the geographic assemblages of capitonids.

The phylogeny of the Ramphastoidea proposed here provides new evidence on the biogeographic history of the group. An area cladogram of the ramphastoids is shown in Fig. 6. The monophyly of the New World capitonids and ramphastids strongly implies that the New World ramphastoids had a single, common biogeographic origin. This clade may have originated either by vicariant isolation of South America from Africa or by dispersal to the New World from Africa or Asia. In the revised DNA-DNA hybridization piciform phylogeny, Sibley \& Ahlquist (1986; C. G. Sibley, personal communication) estimated the date of divergence between the New and Old World ramphastoids at c. $55 \mathrm{~m} . \mathrm{y} . \mathrm{BP}$, supporting a dispersal origin for the New World ramphastoids and discrediting the much older, possible Gondwanaland vicariance origin for 


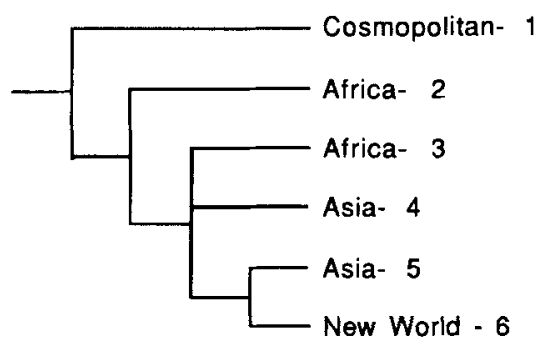

Figure 6. Area cladogram identifying hypothetical vicariance events in the biogeographic history of the capitonids and ramphastids: 1-.. Picoidea; 2--Trachyphonus; 3-Stactolaema, Gymnobucco, Lybius, Tricholaema, Buccanodon and Pogoniulus; 4-Calorhamphus; 5-Megalaima and Psilopogon; 6-Capito, Eubucco, Semnornis and the ramphastids. See Discussion.

the group (Fig. 6). The indication that the New World ramphastoids and the Asian genera Megalaima and Psilopogon comprise a clade further implies an Asian, dispersal origin for the New World radiation. It is clear that the African capitonids are not monophyletic and could not have originated from a single dispersal event, as proposed by Ripley (1945, Fig. 6). The African capitonids excluding Trachyphonus may have been a secondary colonization of Africa from Asia, perhaps following the isolation in Asia of the main lineage of ramphastoids from the African Trachyphonus. The unresolved relationships among the main African and Asian radiations, the Asian Calorhamphus and the New World ramphastoids make further speculation about their biogeographic history unsupportable (Fig. 6). Additional phylogenetic information about the interrelationships of these clades may make it possible to reject some hypotheses and possibly support a single scenario for the history of the pantropical distribution of the Ramphastoidea. The discernible patterns in ramphastoid biogeography may be obscured if significant portions of these ramphastoid radiations have gone extinct.

Berlioz (1936), Ripley (1945), Goodwin (1964) and Short (1985) all remarked on how depauperate the New World capitonid fauna is in comparison with the African and Asian radiations. Short (1985) hypothesized that the difference in the sizes of the three geographic radiations of capitonids may have been the result of differences in the amount of ecological competition and nest parasitism, and that the particular diversity of African capitonids resulted from the unique opportunities for repeated recolonization of wooded and grassland habitats. However, as Short (1985) recognized, the species diversity of the African, Asian and Neotropical radiations of ramphastoids is nearly identical if the ramphastids are included with the Neotropical capitonids. It now appears that the answer to the traditional question 'Why are there so few barbets in the New World?' is 'There aren't; there are toucans'.

\section{PROPOSED CLASSIFICATION}

The goal of the phylogenetic classification proposed here is to communicate the hypothesized phylogenetic or cladistic relationships among taxa (Fig. 5) as efficiently and conservatively as possible. In order to minimize the number of redundant categories, I adopt the phylogenetic sequencing conventions summarized by Wiley (1981). Following these conventions, the first taxon in a series of taxa in a single higher category is the sister group to the remaining taxa 
of that rank in that higher category. The term sedis mutabilis is applied here to taxa with unresolved relationships (i.e. polychotomies).

The monophyly of the Capitonidae was not supported by this investigation, so this exclusive taxon is abandoned. I propose that the capitonids and ramphastids be placed in seven subfamilies in the family Ramphastidae, which has priority over Capitonidae. The generic limits follow Short \& Horne (1985) for African taxa and Peters (1948) for Asian and New World taxa. Geographic distributions of each genus are summarized in Table 1:

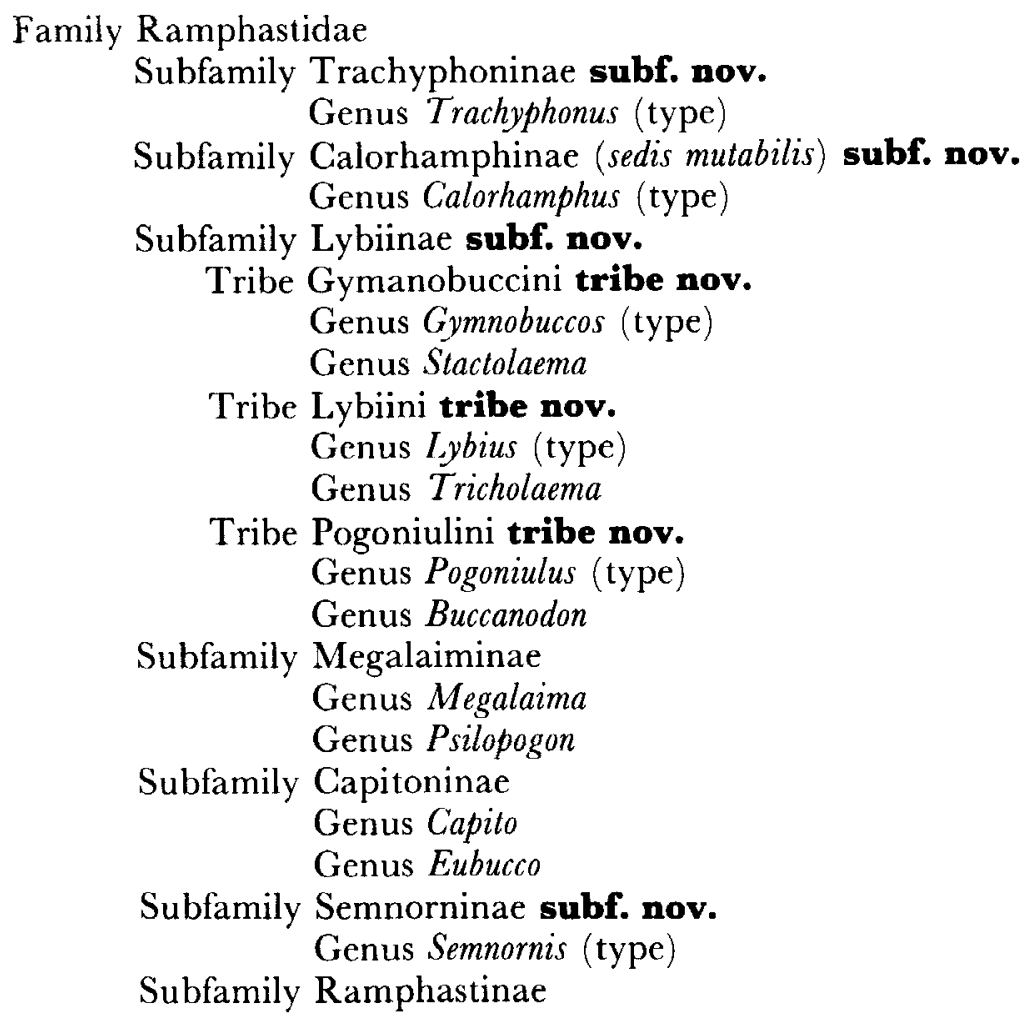

This proposed classification renders the superfamily Ramphastoidea redundant. Following the same sequencing conventions, the Ramphastoidea could be abandoned if the Ramphastidae were placed before the Indicatoridae and the Picidae in the series of families in the suborder Pici (Piciformes sensu stricto), reproducing the phylogenetic relationships supported by Swierczewski \& Raikow (1981) and Simpson \& Cracraft (1981). Based on the discussion above, Capitonides Ballman should be considered as the sister group to the extant Pici and may be placed in the family Capitonididac at the beginning of the sequence:

Suborder Pici

\author{
Family Capitonididae fam. nov. \\ Genus Capitonides (type) \\ Family Ramphastidae \\ Family Indicatoridae \\ Family Picidae
}




\section{ACKNOWLEDGEMENTS}

I would like to thank G. F. Barrowclough of the American Museum of Natural History, J. V. Remsen of the Louisiana State University Museum of Zoology, S. L. Olson of the National Museum of Natural History, and R. B. Payne and R. W. Storer of the University of Michigan Museum of Zoology for lending specimens or allowing me to inspect specimens in their care. The manuscript was greatly improved by comments from and conversations with P. J. K. Burton, P. F. Cannell, J. Cracraft, W. L. Fink, J. Gauthier, S. M. Goodman, R. E. Irwin, M. W. Nachman, R. B. Payne, R. J. Raikow and C. G. Sibley. Margret Van Bolt prepared the osteological illustrations. Funds for computer analyses and illustrations were provided by the Department of Biology, University of Michigan.

\section{REFERENGES}

ALBERCH, P. S., GOULD, S. J., OSTER, G. F. \& WAKE, D. B., 1979. Size and shape in ontogeny and phylogeny. Paleobiology, 5: 296-317.

BALLMANN, P., 1969a. Les oiseaux miocènes de la Grive Saint-Alban (Isère). Géobios, 2: 157-204.

BALLMANN, P., 1969b. Die Vögel aus der altburdigalen Spaltenfüllung von Wintershof (West) bei Eichstätt in Bayern. Zitteliana, 1: 5-60.

BALlMANN, P., 1983. A new species of fossil barbet (Aves: Piciformes) from the Middle Miocene of the Nordlinger Ries (Southern Germany). Journal of Vertebrate Paleontology, 3: 43-48.

BAUMEL, J. J., 1979. Nomina Anatomica Avium. London: Academic Press.

BEDDARD, F. E., 1896. Contributions of the anatomy of picarian birds-Part II. A note upon the pterolysis of the barbets and toucans. Proceedings of the Zoological Society of London (1896): 555-557.

BEDDARD, F. E., 1898. The Structure and Classification of Birds. London: Longmans, Green, \& Co.

BERLIOZ, J., 1936. Etude critique des capitonides de la région orientale. L'Oiseau, 6: 28-56,

BRODKORB, P., 1971. Catalogue of fossil birds: Part 4 (Columbiformes through Piciformes). Bulletin of the Florida State Museum, Biological Sciences, 15, No. 4.

BURTON, P. J. K., 1984. Anatomy of the feeding apparatus in the avian orders Coraciiformes and Piciformes. Bulletin of the British Museum (Natural History), Zoology, 47(6): 331-443.

CRACRAF" T, J, 1968. The lacrimal-ectethmoid bone complex in birds: a single character analysis. American Midland Naluralist, $80: 316-359$.

CRACRAFT, J., 1985. Monophyly and phylogenetic relationships of the Pelecaniformes: a numerical cladistic analysis. Auk, 102: 834-853.

ELDREDGE, N. \& CRACRAFT, J., 1980. Phylogenetic Patterns and Evolutionary Process. New York: Columbia University Press.

FINK, W. L., 1982. The conceptual relationship between ontogeny and phylogeny. Paleobiology, 8: 254-264.

FORBES, W. A., 1882. Note on the gall-bladder, and some other points in the anatomy of toucans and barbets (Capitonidac). Proceedings of the Zoological Society of London, (1882): 94-96.

FURBRINGER, M., 1888. Untersuchungen zur Morphologie und Systematik der Vögel. II Allgemeiner Theil. Amsterdam: Van Holkema.

GARROD, A. H., 1878. Notes on the anatomy of Indicator major. Proceedings of the Zoological Society of London, (1878): $930-935$.

GEORGE, J. C. \& BERGER, A. J., 1966. Avian Myology. New York: Academic Press.

GLENNY, F. H., 1944. A systematic study of the main arteries in the region of the heart. Piciformes. Proceedings of the Zoological Society of London, Series B, 113: 179-192.

GLENNY, F. H., 1955. Modifications of patterns in the aortic arch system of birds and their phylogenetic significance. Proceedings of the United States National Museum 104: 525-621.

GLENNY, F. H. \& AMADON, D., 1955. Remarks on the pigeon Otidiphaps nobilis Gould. Auk, 72: 199-203.

GLENNY, F. H. \& FRIEDMANN, H., 1954. Reduction of the clavicles in the Mesoenatidae with some remarks concerning the relationships of the clavicles to flight-function in birds. Ohio Journal of Sciences, 54: $11]-113$.

GOODWIN, D., 1964. Some aspects of taxonomy and relationships of barbets (Capitonidae). Ibis, 106: 198-220.

HAFFER, J., 1974. Avian speciation in South America. Nuttall Club Publications, No. 14.

HILLEL, E., 1904. Ueber dic Vorderextremität von Eudyptes chrysocome und deren Entwickelung. Jenaishes Zeitschrift für Naturwissenschaft, 38: 725-770.

KLUGE, A. G. \& FARRIS, J. S., 1969. Quantitative phyletics and the evolution of Anurans. Systematic Zoology, 18: 1-32. 
KNOPFLI, W., 1919. Beiträge zur Morphologie und Entwicklungsgeschichte des Brustschulterskclets bei den Völgeln. Jenaishe Zeitschrift für Naturwissenschaft, 55: 557-720.

LANYON, S. M., 1985. Molecular prospectives on higher-level relationships in the Tyrannoidea (Aves). Systematic Zoology, 34: 404-418.

LILLIE, F. R., 1919. The Development of the Chisk. New York: Holt \& Co.

LOWE, P. R., 1946. On the systematic position of the Woodpeckers (Pici), Honey-guides (Indicator) Hoopoes, and others. Ibis, 88: 103-127.

McKITRICK, M. C., 1985. Monophyly of the Tyrannidae (Aves): comparison of morphology and DNA. Systematic Zoology, 34: 34-45.

MADIISON, W. P., DONOGHUE, M. J. \& MADDISON, D. R., 1984. Outgroup analysis and parsimony. Systematic Zoology, 33: 83-103.

MAILLARD, J, 1948, Recherches embryologique sur Catharacta skua Brunn. (Pterylose et ossification). Revues Suisse de Zoologie, Tome 55, Fascicule Supplémentaire, No. 1: 1-114.

MARSHALL, C. H. T. \& MARSHALL, G. F. L., 1870. A Monograph of the Capitonidae or the Scansorial Barbets. London.

MILLER, W. D., 1915. Notes on ptilosis, with special reference to the feathering of the wing. Bulletin of the American Museum of Natural History, 34; 129-140.

MILLER, W. D., 1924. Further notes on ptilosis. Bulletin of the American Museum of Nalural History, 50: 305-33I.

NITZSCH, C. L., 1840. System der Pterylographie. Halle: Edouard Anton.

NI'I'ZSCH, C. L., 1867. Nitzsch's pterylography. [English translation, P. L. Sclater, Ed.] London: Ray Society.

NEWTON, A., 1899. A Dictionary of Birds. London: Adam and Charles Black.

OLSON, S. I. 1983. Evidence for a polyphyletic origin of the Piciformes. Auk, 100:126-133.

OLSON, S. L., 1985. The fossil record of birds. In D. S. Farner, J. R. King, K. C. Parkes (Eds), Avian biology, VIII: 80 238. Orlando, Florida: Academic Press.

OWEN, R., 1833(-1835). On the anatomy of the toucan. In J. Gould Monograph of the Ramphastidae. London.

PARKER, W. K., 1867. A Monograph on the Struture and Development of the shoulder-girdle and Sternum in the Vertebrata. London: Ray Society.

PARKER, W. K., 1875. On the morphology of the skull in the woodpeckers (Picidac) and Wrynecks (Yungidae). Transactions of the Linnean Society of London, Second Series, 1: 1-22.

PETERS, J. L., 1948. Check-list of Birds of the World, VI. Cambridge: Harvard University Press.

PRUM, R. O., 1982. The systematics and biogengraphy of the family Ramphastidae (Aves). Unpublished senior honors thesis, Harvard University.

RAIKOW, R. J., 1982. Monophyly of the Passeriformes: test of a phylogenetic hypothesis. Auk, 99: 431-445.

RAIKOW, R.J. \& CRACRAF"I, J., 1983. Monophyly of the Piciformes: a reply to Olson. Auk, 100: I34-138.

RIDGWAY, R, 1914. The birds of North and Middle America. Part V1. Bulletin of the United States Nalional Museum, No. 50 .

RIPLEY, S. D., 1945. The barbets. Auk, 62: 542-563.

ROMANOFF, A. L., 1960. The Avian Embryo. New York: MacMillan Co.

ROMER, A. S., 1970. The Vertebrate Body. Philadelphia: Saunders.

SCLATER, P. L., 1861. On the American barbets. Ibis, 3: 182-190.

SCLATER, P. L., 1891. Calalogue of the Picariae in the Collection of the British Museum. London: British Museum (Natural History).

SEEBOHM, H., 1890. An attempt to diagnose the Pico-Passerine birds and the suborders of which it consists. Ibis, 32: $29-37$.

SHORT, L. L., 1985. Neotropical-Afrotropical barbet and woodpecker radiation: a comparison. In P. A. Buckley, M. S. Fosier, P. A. Morton, R. S. Ridgley \& F. G. Buckley (Eds), Neolropical Ormithology: 559-574. Ornithological Monographs, No. 36. Washington, D.C.: American Ornithologists' Union.

SHOR'T, L. I.. \& HORNE, J. F. M., 1980. Ground barbets of East Africa. The Living Bird, 18: 179-186.

SHOR'T, L. L. \& HORNE, J. F. M., 1985. Social behaviour and systematics of the African barbets (Aves: Capitonidac). In K.-L. Schuchmann (Ed.), Proceedings of the International Symposium on African Vertebrates. 255 278. Bonn: Zoologisches Forschungsinstitut und Museum Koenig.

SHUFELDT, R. W., 1891. On the question of saurognathism of the Pici, and other osteological notes upon that group. Proceedings of the Zoological Society of London, (1891): 122-129.

SIBLEY, C. G. \& AHLQUIST, J. E., 1972. A comparative study of the egg white proteins of non-passerine birds. Peabody Museum of Natural History Bulletin, No. 39.

SIBLEY, C. G. \& AHLQUISI, J. E., 1983. Phylogeny and classification of birds based on the data of DNA-DNA hybridization. Current Ornithology, $1: 245-292$.

SIBIEY, C. G. \& AHLQUIST, J. E., 1985. The rclationships of some groups of African birds, based on comparisons of the genetic material, DNA. In K.-L. Schuchmann (Ed.), Proceedings of the International Symposium on African Vertebrates: 115-161. Bonn: Zoologisches Forschungsinstitut und Museum Koenig.

SIBLEY, C. G. \& AHLQUIST, J. E., 1986. Reconstructing bird phylogeny by comparing DNA's. Scientific American, 254(2): $82-92$

SIMPSON, S. F. \& GRACRAFI, J., 1981. The phylogenetic relationships of the Piciformes (Class Aves). Auk, 98: $481-494$ 
STEVENS, P. F., 1980. Evolutionary polarity of character states. Annual Review of Ecology and Systematics, 11: 333-358.

STRESEMANN, E., 1934. Sauropsida: Aves. In T. Krumbach (Ed.) Handbuch der Zoologie, 17, Part 2. Berlin: W. de Gruyter.

SWIERCZEWSKI, E. V. \& RAIKOW, R. J., 1981. Hind limb musculature, phylogeny and classification of the Piciformes. $A u k, 98: 466-480$.

SWOFFORD, D. L., 1983a. Phylogenetic Analysis using Parsimony (PAUP) Computer Algorithm. Version 2.3. Champaign, Illinois: Illinois Natural History Survey.

SWOFFORD, D. L., 1983b. Consensus Tree (CONTREE) Computer Algorithm. Version 5. Champaign, Illinois: Illinois Natural History Survey.

VAN TYNE, J. \& BERGER, A. J., 1959. Fundamentals of Omithology. New York: John Wiley \& Sons.

VERHEYEN, R, 1955. Contribution à la systématique des Piciformes basée sur l'anatomic comparće. Institut royal des Sciences naturelles de Belgique. Bulletin, Tome 31, No. 50-5l.

WETMORE, A., 1960. A classification for the birds of the world. Smithsonian Miscellaneious Collections, 139, No. 11 .

WILEY, E. O., 1981. Phylogenetics. New York: John Wiley \& Sons.

WOLTERS, H. E., 1976. Die Vogelarten der Erde. 2. Lieferung. Hamburg: Verlag Paul Parey.

WOOD, D. S., ZUSI, R. L. \& JENKINSON, M. A., 1982. World Inventory of Avian Skeletal Specimens, 1982. Norman, Oklahoma: American Ornithologsts' Union and the Oklahoma Biological Survey.

\section{APPENDIX: SKELETAL MATERIAL EXAMINED}

For the Coraciiformes, Galbulae, Picoidea and Ramphastidae, observations were made of the skeletal collections of the University of Michigan Museum of Zoology, Ann Arbor, Michigan (sec Wood, Zusi \& Jenkinson, 1982 for summary of these holdings). The following skeletal specimens of capitonids were observed from the collections of the American Museum of Natural History (AMNH), New York; the Louisiana State Lniversity Museum of Zoology (LSUMZ), Baton Rouge, Louisiana; the National Museum of Natural History (formerly, USNM), Washington, D.C.; and the University of Michigan Museum of Zoology (UMMZ), Ann Arbor, Michigan (partial or damaged specimens are followed by an asterisk).

Trachyphonus purpuratus USNM 291093; Trachyphonus vaillantii AMNH 2575, UMMZ 219892; Trachyphonus erythrocephalus UMMZ $216811^{*}$; Trachyphonus daurnaudii UMMZ 156683, 156684, 208314, 216812; Gymnobucco peli USNM 291090; Gymnobucco bonapartei UMMZ 208313, 216799*; Stactolaema anchietae UMMZ 216802*, 216803*; Stactolaema leucotis AMNH 13456; Lybius vielloti UMMZ 203869; Lybius torquatus AMNH 2376, 2634, 9160, 9161, 9162*, 9163, UMMZ 152680, 215464, 218555; Lybius guifsobalito AMNH 3960, UMMZ 216808; Lybius minor UMMZ 218729; Lybius bidentatus AMNH 4863, 4864, 14292; Lybius dubius AMNH 8284; Tricholeama lacrymosum UMMZ 158580, 158581; Tricholaema diadematum UMMZ 156679, 156680, 156681; Tricholaema hirsutum AMNH 6158; Pogoniulus chrysoconus UMMZ 156682, 204614; Pogoniulus bilineatus UMMZ 218554; Buccanodon duchaillui USNM 291795; Calorhamphus fuliginosa AMNH 987*, UMMZ 158280; Megalaima lineata AMNH 8295, UMMZ 218047; Megalaima corvina AMNH 438; Megalaima chrysopogon AMNH 437, UMMZ 158281; Megalaima raflesii UMMZ 214555; Megalaima mystacophanos AMNH 8712, UMMZ 214554; Megalaima javensis AMNH 436, 4958; Megalaima asiatica AMNH 2501, 4684, 6333; Megalaima henricci AMNH 435; Megalaima haemacephala AMNH 6330, 10988, UMMZ 210988, 216186; Psilopogon pyrolophus USNM 558259; Capito aurovirens LSUMZ 68741, 68742, 118370, 121043, 121044; Capito maculocoronatus LSUMZ 108764; Capito niger UMMZ 159409, 156868, 157642, 216113; Eubucco bourcierii AMNH 5826, UMMZ 216185, USNM 491381; Eubucco versicolor LSUMZ 70220, 89708, 99342; Semnornis frantzii UMML 133835; Semnornis ramphastinus AMNH 5658, UMMZ 152365, 154517. 